\title{
Study of the Implementation of Fibrous Materials and Earth in Hollow Body Slab in Reinforced Concrete: Case of Laterite, Borassus Aethiopum and Calamus Deerratus Woods
}

\section{Yemalin Daniel Agossou \\ Universite de Lorraine}

Thomas Dèkandji Ekpo

Universite Nationale des Sciences Technologies Ingenierie et Mathematiques

Rémi Boissiere

Université de Lorraine

Edmond Codjo Adjovi ( $\sim$ adjed2012@gmail.com )

UNSTIM: Universite Nationale des Sciences Technologies Ingenierie et Mathematiques

https://orcid.org/0000-0002-5382-8499

\section{Edem Chabi}

Université Nationale d'Agriculture

\section{T. Armel Amadji}

Universite d'Abomey-Calavi

Abdelouahab Khelil

Universite de Lorraine

\section{Research Article}

Keywords: Construction materials, lateritic earth, Borassus aethiopum, Calamus deerratus, reinforced concrete, hollow-body slabs

Posted Date: March 2nd, 2021

DOI: https://doi.org/10.21203/rs.3.rs-264232/v1

License: (c) (i) This work is licensed under a Creative Commons Attribution 4.0 International License. Read Full License

Version of Record: A version of this preprint was published at Waste and Biomass Valorization on July 14th, 2021. See the published version at https://doi.org/10.1007/s12649-021-01510-1. 

Study of the implementation of fibrous materials and earth in hollow body slab in reinforced concrete: case of laterite, Borassus aethiopum and Calamus deerratus woods Yémalin Daniel Agossou 1, 2, 3. Thomas Dekandji Ekpo'. Rémi Boissiere³ . Edmond Codjo Adjovi $^{1,2}$. Edem Chabi ${ }^{4}$. S. Armel Amadji² ${ }^{2}$ Abdelouahab Khelil ${ }^{3}$.

${ }^{1}$ National Superior School of Public Works. National University of Sciences, Technologies, Engineering and Mathematics. BP 2282 Abomey. Bénins

${ }^{2}$ Doctoral School of Engineering Sciences. University of Abomey-Calavi. 01 BP 2009 Cotonou. Bénin

${ }^{3}$ Jean Lamour Institute. University of Lorraine. IUT Brabois - Rue du Doyen Urion CS 90137. France

${ }^{4}$ School of Rural Engineering. National University of Agriculture. 01 BP 55, Porto-Novo. Bénin

Corresponding author: Adjovi Edmond Codjo, Professor

Telephone: (00299) 97139069

E-mail address: adjed2012@gmail.com

\begin{abstract}
This work enrolls in the context of eco materials. It concerns the field of transformation of local shrub forest resources and lateritic earth with low market values into building materials and is developing a process for the valorization of lateritic nodules, Borassus aethiopum (palmyra) and Calamus deerratus (rattan) in the engineering of modern reinforced concrete structures. The objective of this process is to promote the rational use of these local materials in the realization of the floors of social housing. Experimental studies of physical and mechanical characterizations of the lateritic concrete formulated, of the palmyra and rattan woods were carried out. Through tests of tearing and sliding of the interface between normal concrete and laterite concrete (push-out tests), it has been highlighted the adhesion of palmyra wood to concrete and the contribution of rattan lianas to oppose the longitudinal sliding of the interface between two concretes of different nature. The case study of a hollow body slab in mixed concrete (normal and laterite concrete) reinforced with palmyra and rattan woods,
\end{abstract}


showed the structural effectiveness of lateritic earth, of palmyra and rattan woods in the realization of social housing modern slads with a range of up to 5 meters.

\section{Graphic Abstract}

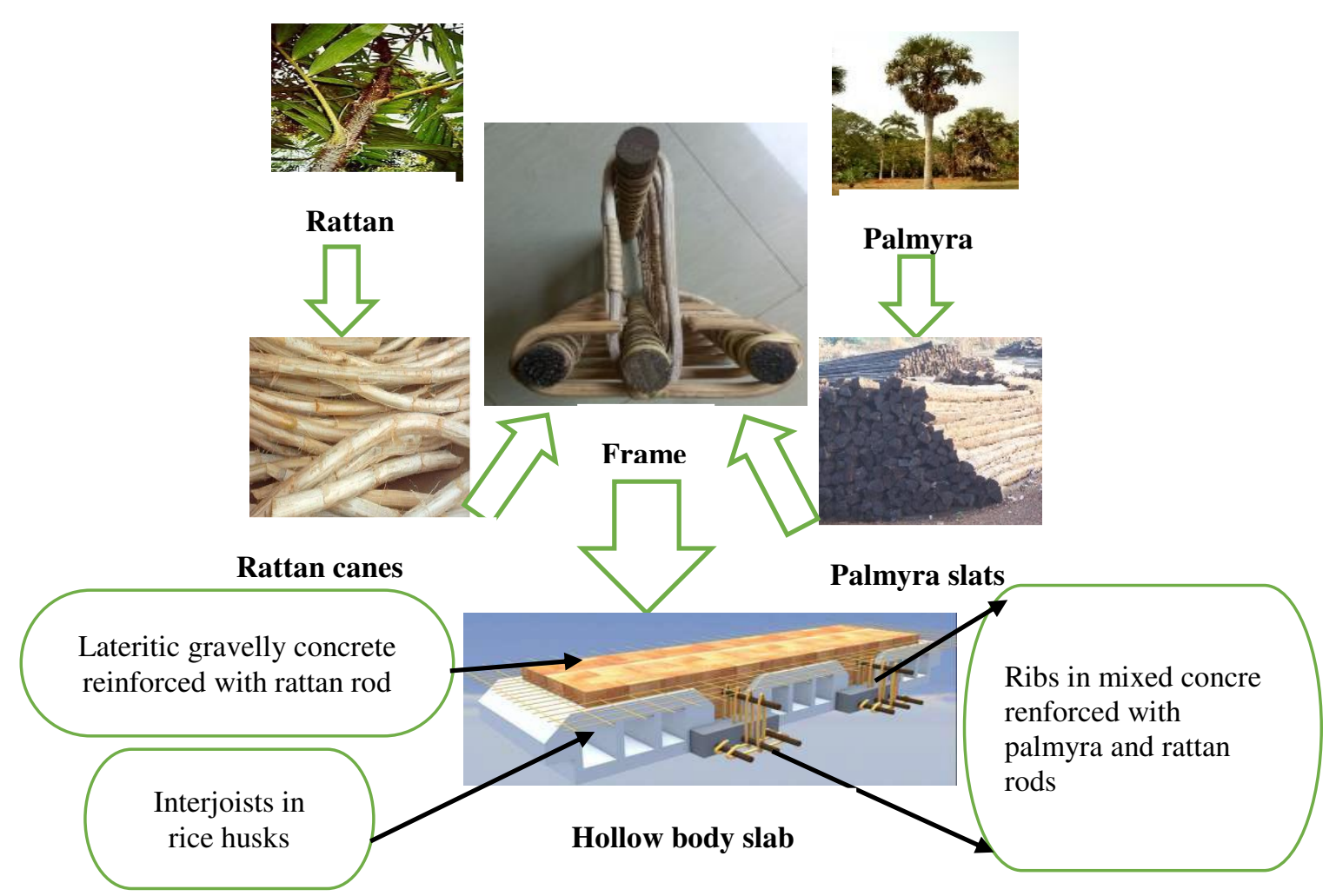

\section{Keywords}

Construction materials, lateritic earth, Borassus aethiopum, Calamus deerratus, reinforced concrete, hollow-body slabs

\section{Statement of Novelty}

The Borassus aethiopum and Calamus deerratus are monocots, the wood of which is used in a disproportionate way in the realization of the structures of traditional earthen construction. This process does not contribute to the rational use of the shrub plant cover.

The innovations brought by this work are:

- The tensile behavior and mechanical characteristics of the frames in palmyra and rattan woods have been described, 
- a method for formulating lateritic gravelly concrete based on the total sum of the absolute volumes of each component added to the volume of entrained air and trapped air corresponding to one cubic meter of concrete was developed,

- a process for valuing Borassus aethiopum and Calamus deerratus woods and laterite was developed. 


\section{Introduction}

Rural communities in developing countries have significant deposits of local building materials among which we have: the palmyra (Borassus aethiopum), rattan (Calamus deerratus) (Fig. 1) and laterite. The local materials obtained from these natural resources were used in West Africa in the traditional and semi-modern construction practice, respectively by the villagers and the colonizer to build the housings (Fig. 2).

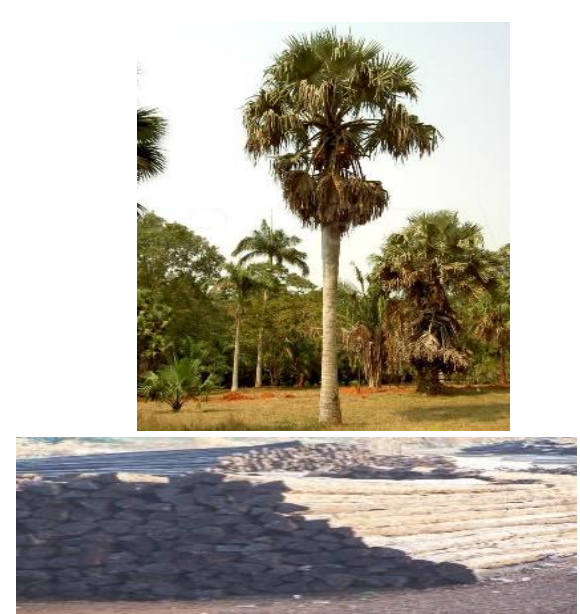

a

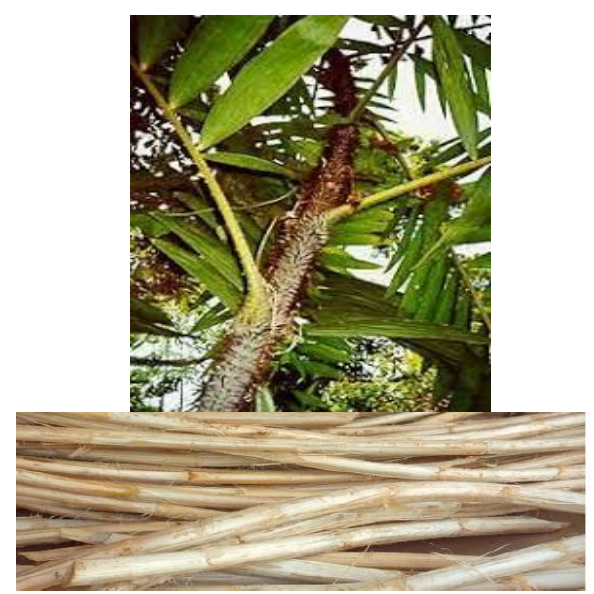

b

Fig. 1 a Borassus aethiopum (palmyra wood slats); b Calamus deerratus (rattan lianas)

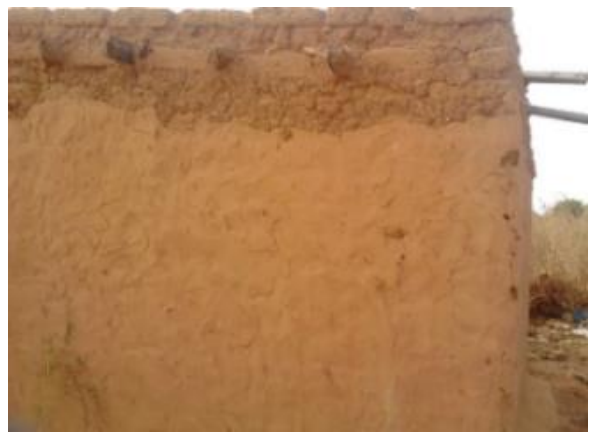

a

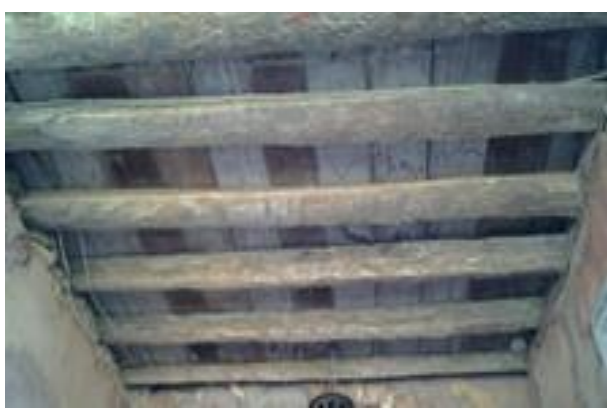

b

Fig. 2 a Rural housing in a locality in Niger / West Africa; b Palmyra wood-laterite slab on the Island of Goree / Senegal

In the context of modernity and construction methods using conventional sand mortar and cement, reinforced concrete and corrugated sheets, these green building practices have disappeared in the cities and are gradually disappearing in the villages. Thus, we are increasingly observing the establishment of housing made of modern materials in rural villages/ towns, although since the 1970s, many researchers, with the aim of promoting the use of eco 
materials in buildings modern, examine the issue of substitution of sea sands, gravel/crushed and steel, respectively by laterite/lagoon sand, laterite nodule [1-11], rice husks [12-15] and certain woody forest products [16-24]. Other researchers have used waste materials to improve the mechanical properties of rammed earth structures [25-29].

It is to reverse this trend, that we propose in this work the study of a possibility of using mixed concrete (conventional aggregate concrete and concrete with sand and lateritic gravel) reinforced, with original reinforcements vegetable palmyra wood and rattan lianas) in a hollow body slab which is of the range of modern structures of housing in urban cities.

If we analyze the stressing modes of the components of a hollow-body slab, we observe, that the ribs and the compressive table are stressed in simple flexion and simple compression respectively, while the interjoists serve as filling.

Considering that:

- the palmyra wood and rattan wood have a certain capacity of tensile / shear strengh and of concrete adhesion,

- the laterite concrete associated with rattan wood has a good compressive strength,

- the interjoists in rice husks [12-15] have a thermal insulation capacity and a low density, we can without hesitation design slabs (Fig. 3) with these eco-materials with low market value, so we could get solid, insulating, lightweight slabs.

Indeed, lateritic soils are compatible with cement paste. Lateritic sand and nodules can partially or totally replace conventional sand and gravel / crushed respectively, when they are used in optimal proportions with optimal water to cement ratio. Consequently, the density and the compressive strength of the hardened concrete thus obtained can reach respectively a value between 22 and $26 \mathrm{kN} / \mathrm{m}^{3}$, and 12 and $35 \mathrm{MPa}[6,9,10]$, while their workability of these concretes is between 2 and $10 \mathrm{~cm}$ (slump test).

The relatively recent studies on the substitution of steels by vegetable reinforcements in the flexed structures of buildings and which concern the highlighting of the contribution of rattan lianas and bamboo to the mechanical resistance of unreinforced concrete beams, revealed, that the problem of using fibrous materials is the influence of their hygroscopic property, the adhesion to concrete and their low tensile strength compared to that of steel. So, Obilade and Olutoge [17] studied the flexural characteristics of rattan cane reinforced concrete beams. Some beams were reinforced with rattan cane, others with steel and the rest unreinforced. The concrete used has a compressive strength of $20 \mathrm{MPa}$ at 28 days, the diameter of the steel and 
rattan being $12 \mathrm{~mm}$. For singly rattan cane reinforced concrete beam, the load carrying capacity increased by about $20 \%$ over that of the plain concrete beam having the same dimensions. For singly steel reinforced concrete beam, the load carrying capacity increased by about 2.3 times over that of the plain concrete beam having the same dimensions. Mahzuz et al. [19] evaluated the effectiveness of using rattan (Calamus guruba) as reinforcement in concrete beam. The rattan was used as a longitudinal and transverse reinforcement in order to have its physical contribution. The load capacity of rattan reinforced beams has increased by up to $23.5 \%$ compared to the capacity of unreinforced beams. They therefore concluded that rattan can be used for lightly loaded structural- Ngouadjeu [21] examined the technical possibilities of using large rattan (Laccosperma secundiflorum) in concrete for constructions. From his work, it emerges that the use of rattan as a reinforcement in lightly loaded structures and small span beams is possible. Gill and Kumar [22] experimentally investigated the possibility of using bamboo as reinforcement in structural members of civil engineering. They noted that the loadbearing capacity of a reinforced bamboo beam increased about 3 times than that of unreinforced concrete of the same dimensions. The tensile strength of bamboo can be up to $400 \mathrm{MPa}$, the bond strength of treated bamboo concrete is between 1.2 and 1.35 MPa. From these results, they concluded that bamboo can be used as a reinforcement for structures as long as they are lightly loaded. However, the humidity level directly affects the physical and mechanical characteristics of bamboo. Adewuyi et al. [23] conducted a comparative study of the tensile and flexural strengths of steel, bamboo (Bambusa vulgaris) and rattan (Calamus deerratus), as reinforcement in concrete. Using the same diameter, they obtained a yield strength of bamboo and rattan bars respectively of $13 \%$ and $45 \%$ of that of steel (442.73 MPa) and an ultimate resistance of about $16 \%$ and $62 \%$ of steel $(540.13 \mathrm{MPa})$ in the same order. The flexural strengths of reinforced bamboo, rattan and steel beams are respectively 6.22, 2.56 and 12.22 MPa. This remarkable difference between the resistances may be due not only to the tensile strength, but also to the weak bond at the bamboo-concrete interface. They concluded that bamboo bars are suitable reinforcements for lightly loaded bending structures, while more reinforced processing is needed for rattan to improve inter-facial bonding and load-bearing capacity.

Further studies on the use of fibers for improving the mechanical properties of earthen structures have been carried out. So, Zare et al. [27] used Waste Tire Textile Fibers (WTTFs) to improve the mechanical properties of non-stabilized and cement-stabilized rammed earth structures. The results of the work have shown that WTTFs improve the compressive and tensile strength of rammed earth structures and ductility of these structures. The authors also concluded that fibers 
and cement can be used simultaneously to improve the maximum load capacity. Ajouguim et al. [26] conducted research on the feasibility of using fibers extracted from the Moroccan Alfa plant as a reinforcement for compacted earth bricks. Alpha fibers have been modified by alkaline and hydrothermal treatments. Adding $1 \%$ by weight of the treated Alfa fibers in solution $(\mathrm{NaOH}, 6 \%)$ provided the best mechanical properties and low conductivity value. Ige and Danso [29] used plantain pseudo-stem fibers to reinforce adobe masonry units. The average compressive strength obtained varies between 1.18 and $1.76 \mathrm{MPa}$, the compressive strength of unreinforced adobe being 0.30 MPa at most. That's an improvement of at least $30 \%$. As for the tensile strength, there is an improvement of $53 \%$.

Against this background, the aim of this study is to present the process of valorization of palmyra and rattan woods and of lateral gravels for the realization of slabs with hollow bodies in laterite concrete and normal concrete. This process consists of:

- obtaining longitudinal (main) reinforcing bars for ribs or joists,

- obtaining the transverse reinforcing bars of the ribs or joists and grid reinforcements of the compression table of the slab,

- physical and mechanical characterization of palmyra and rattan woods,

- the formulation and characterization of the lateritic nodules concrete,

- the study of the use of Palmyra wood and rattan wood in concrete.

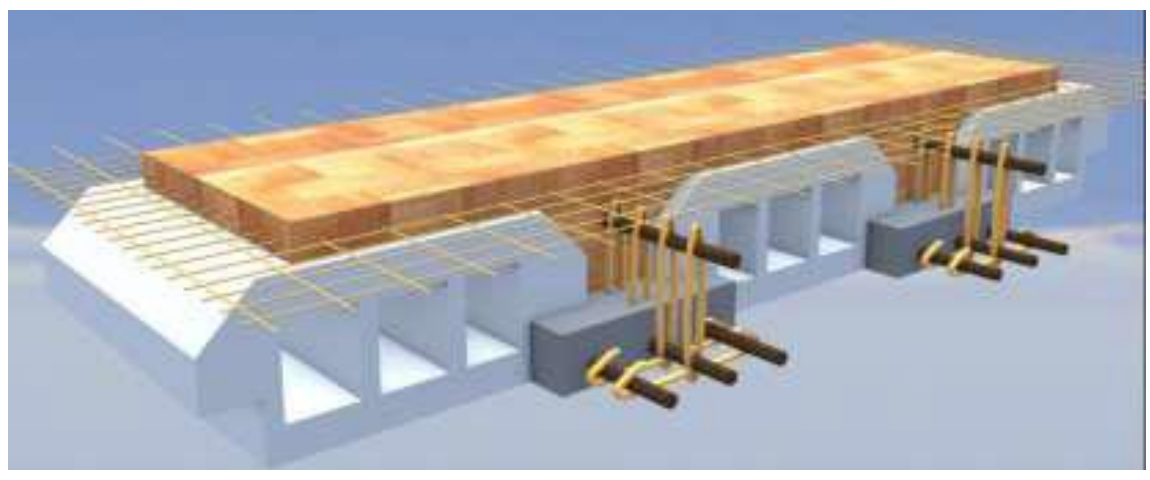

Fig. 3 Model of hollow-body slab made of latérite concrete, lagoon sand concrete, palmyra and rattan reinforcements and interjoists in rice husks 


\section{Materials and methods}

\section{Obtaining longitudinal reinforcing bars}

After felling the palmyra tree, the stipe is harvested. From the outer crown of this stipe, slats are taken. These slats have a section of $4 \times 4 \mathrm{~cm}^{2}$ or $4 \times 6 \mathrm{~cm}^{2}$ depending on the thickness of the outer crown. These lattess are machined from rods or cylindrical bars with diameters between 15 to $30 \mathrm{~mm}$. The rods are then characterized by physical and mechanical tests.

\section{Obtaining transverse reinforcing bars and grid bars}

After harvesting the stipe of the rattan, it is scraped to remove the bark and take out the cane. The cane is then straightened and dried to allow better conservation. Rods that can be used as reinforcing rods must have a diameter between 10 and $15 \mathrm{~mm}$. Their use as reinforcement requires physical and mechanical characterization tests.

\section{Physical and mechanical characterization of palmyra and rattan woods}

The rattan and palmyra woods used for this work come from the forests of Benin (West Africa). The tests carried out on these materials concern the humidity rate, the density, the absorption, the shrinkage, the swelling, the tensile and the compression.

The humidity rate $\mathrm{H}(\%)$ is measured in accordance with Standard NF B 51-004 [30].

The density $\left(\mathrm{g} / \mathrm{cm}^{3}\right)$ is measured according to the protocol described by standard NF B51005 [31].

The water quantity, that the plant materials used, can absorb is measured according to the experimental approach of standard NF EN 1097-6 [32].

The volumic shrinkage and swelling of the test pieces having a humidity equal or greater, than the saturation point of the cell walls and reduced to the anhydrous state are measured according to standard NF B51-006 [33].

The tensile tests of the test pieces were made in accordance with standards NF B51-017 [34], NF B51-018 [35].

The tensile tests of the test pieces were performed on the whole in accordance with standards NF B51-017 [34], NF B51-018 [35]. The palmyra wood sample used had prismatic shape and its dimensions $4 \times 20 \times 200 \mathrm{~mm}^{3}$ followed the orthotropic directions of the palmyra tree. For the rattan wood, sample were directly cut on natural shape of the species under diameter of $9 \mathrm{~mm}$ and length of $200 \mathrm{~mm}$. Displacement of sample during the test were captured using a device 
including a camera, two digital comparators and two rigid plates sticked on the sample (and in contact with the comparator probe) at a relative distance $\mathrm{L}_{0}=100 \mathrm{~mm}$. Deformation were calculated by dividing the difference of displacements displayed on comparators by the relative distance $\mathrm{L}_{0}$. The cross head speed during the test were $4 \mathrm{~mm} \cdot \mathrm{s}^{-1}$.

\section{Formulation and physical and mechanical characterization of laterite concrete}

\section{Formulation of laterite concrete}

The lateritic earth used in this work is taken from a quarry located in the south of Benin (West Africa) in the commune of Allada. It is separated into two classes: sand and nodule of calibers $0 / 5$ and 5/45, respectively. The curve representing the weight distribution of the various aggregates contained in the lateritic soil is presented in Fig. 4. The absolute density of the passers-by in the $0.08 \mathrm{~mm}$ sieve is $2.661 \mathrm{~g} / \mathrm{cm}^{3}$. The methylene blue value is 0.66 , the sand equivalent is 21.96 . The Atterberg limits: liquidity limit is $40 \%$, the plasticity limit is $21 \%$ and the plasticity index is $19 \%$. The raw laterite in study contains $28.26 \%$ of particles of dimension less than $80 \mu \mathrm{m}, 32.12 \%$ of particles of diameter included in $80 \mu \mathrm{m}$ and $4 \mathrm{~mm}$ (sand) and $39.62 \%$ of nodules (particles of diameter included between $4 \mathrm{~mm}$ and $25 \mathrm{~mm}$ ).

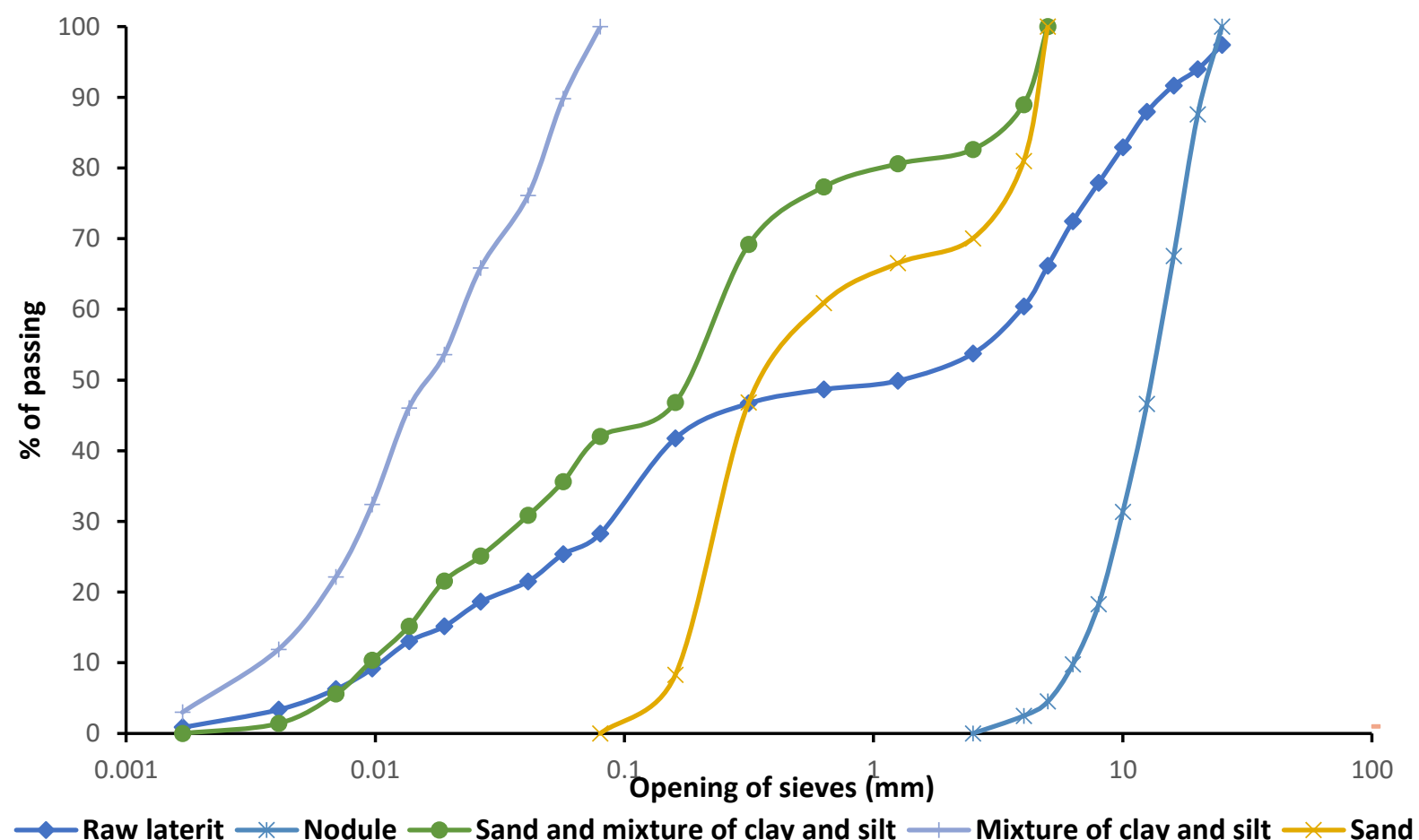

Fig. 4 Granulometry curves of raw laterite and of the granular classes used 
The type of cement used for the formulation is CEMII / B-LL 42.5. It is a quick setting cement. Its minimum compressive strength at 28 days is evaluated at $42.5 \mathrm{MPa}$. Its absolute density is $3.04 \mathrm{~g} / \mathrm{cm}^{3}$.

The method of formulation which we retained in this work is that of the absolute volumes. It is based on the total sum of the absolute volumes of each constituent plus the volume of entrained air and trapped air corresponding to one cubic meter of concrete.

For the formulation of concrete, we considered aggregates of granular classes:

$4 \leq \mathrm{d}<25$ for lateritic nodules $(\mathrm{N})$,

$0<\mathrm{d}<4$ for lateritic sand $(\mathrm{S})$,

Then, we made three mixtures according to the proportions: $\mathrm{N} / \mathrm{S}=\{2.2 ; 2.5 ; 2.8\}$.

The physical characteristics and the particle size curve of the mixture nodules and the sand lateritic for $\mathrm{N} / \mathrm{S}=2.8$ are shown in Table 1 and Fig. 5 .

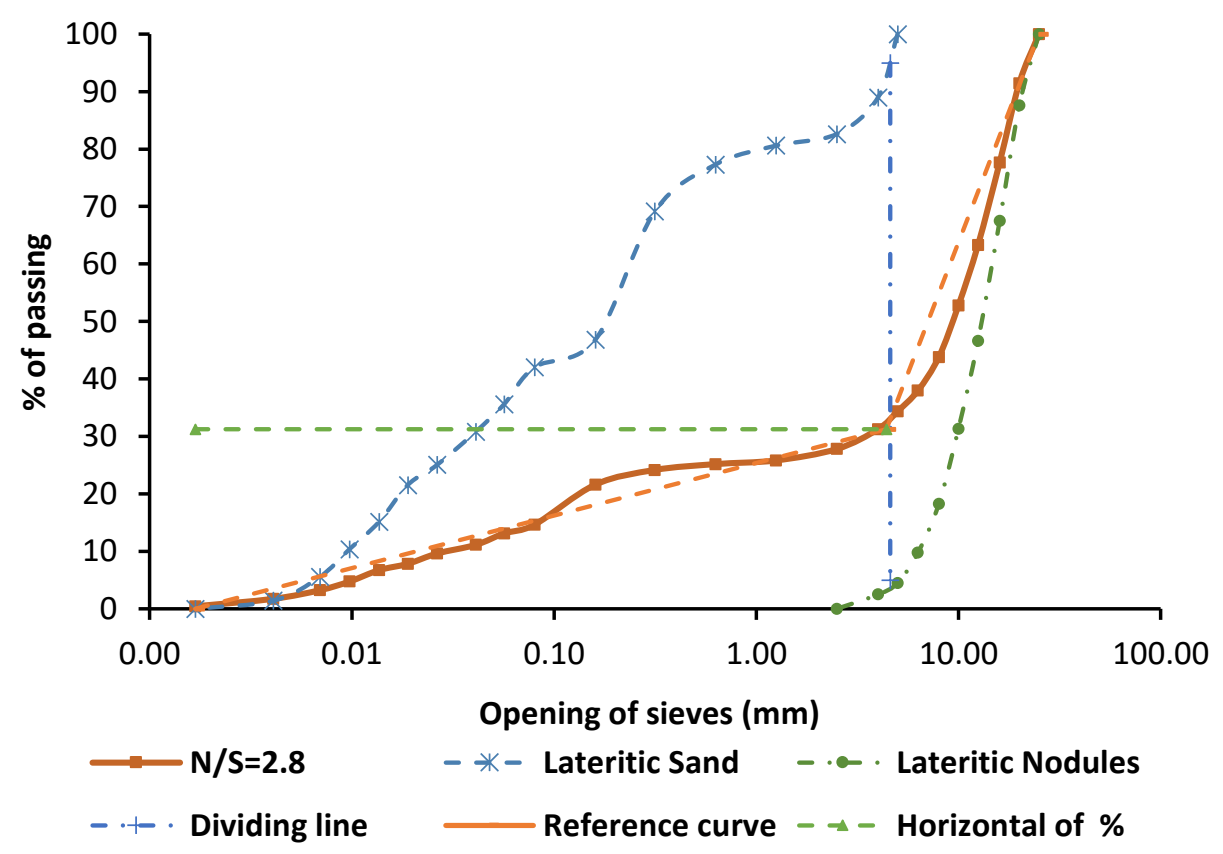

Fig. 5 Granulometric curve of the granular composition of sand and nodules lateritic $(\mathrm{N} / \mathrm{S}=2.8)$ 
Table 1 Physical characteristics of aggregates by granular class

\begin{tabular}{ccccc}
\hline & \multicolumn{3}{c}{ Physical characteristics } \\
\cline { 2 - 5 } Aggregates & $\begin{array}{c}\text { Apparent } \\
\text { volumetric mass } \\
\left(\mathrm{g} / \mathrm{cm}^{3}\right)\end{array}$ & $\begin{array}{c}\text { Absolute } \\
\text { volumetric mass } \\
\left(\mathrm{g} / \mathrm{cm}^{3}\right)\end{array}$ & $\begin{array}{c}\text { Actual volumetric } \\
\text { mass } \\
\left(\mathrm{g} / \mathrm{cm}^{3}\right)\end{array}$ & $\begin{array}{c}\text { Absorption } \\
(\%)\end{array}$ \\
\hline $\begin{array}{c}\text { Nodules } \\
(4 / 25)\end{array}$ & $1.613 \pm 0.038$ & $2.822 \pm 0.080$ & $2.575 \pm 0.006$ & $4.6 \pm 0.46$ \\
\hline Sand $(0 / 4)$ & $1.543 \pm 0.026$ & $2.84 \pm 0.140$ & $2.646 \pm 0.028$ & $2.5 \pm 1.06$ \\
\hline
\end{tabular}

Laterite concrete is obtained on the basis of the following expression:

$$
\frac{c}{\rho_{c}}+\frac{s}{\rho_{S}}+\frac{E}{\rho_{E}}+\frac{N}{\rho_{N}}+V_{V}=1
$$

where, $\rho_{\mathrm{c}}=$ density of the cement $\left(\mathrm{kg} / \mathrm{m}^{3}\right) ; \rho_{\mathrm{S}}=$ density of the sand $\left(\mathrm{kg} / \mathrm{m}^{3}\right) ; \rho_{\mathrm{N}}=$ density of the nodules $\left(\mathrm{kg} / \mathrm{m}^{3}\right) ; \rho_{\mathrm{E}}=$ density of water $\left(\mathrm{kg} / \mathrm{m}^{3}\right) ; \mathrm{C}=$ mass of cement $(\mathrm{kg}) ; \mathrm{S}=$ mass of lateritic sand $(\mathrm{kg}) ; \mathrm{N}=$ mass of nodules $(\mathrm{kg}) ; \mathrm{E}=$ mass of water $(\mathrm{kg}) ; \mathrm{V}_{\mathrm{V}}=$ absolute volume of entrained voids and / or voids trapped in concrete $\left(\mathrm{m}^{3}\right)$.

The unknowns of (1) being the proportions of aggregates, the cement dosage, the quantity of water and the voids. If we take $k_{e}$, the ratio $\frac{\mathrm{E}}{\mathrm{C}}, k_{n}$, the ratio $\frac{\mathrm{N}}{\mathrm{S}}$ and put them in (1), we obtain:

$$
S=\frac{\left(1-V_{V}\right)-C\left(\frac{1}{\rho_{c}}+\frac{k_{e}}{\rho_{E}}\right)}{\frac{1}{\rho_{S}}+\frac{k_{n}}{\rho_{N}}}
$$

Not being able to study all the parameters at once, we set certain constants as follows:

- cement dosage $\mathrm{C}=400 \mathrm{~kg} / \mathrm{m}^{3}$,

- $\quad k_{n}=2.2 ; 2.5$ and 2.8 ,

- $\quad k_{e}=0.40-0.7$,

- $\mathrm{Vv}=15 \%$.

The mass of water $\mathrm{E}$ is corrected by taking into account the absorption of the aggregates. This quantity is corrected by:

$$
E_{c o r}=E+\left(W A_{n}-w_{n}\right) \cdot N+\left(W A_{s}-w_{s}\right) \cdot S
$$

where, $W A_{i}=$ absorption coefficient of the material, $w_{i}=$ water content of the material. 
The density of hardened concrete is calculated by the expression $\frac{\mathrm{m}}{\mathrm{V}}$, where $\mathrm{m}$ and $\mathrm{v}$ are respectively the mass and the volume of the test piece.

\section{Physical and mechanical characterization of laterite concrete}

Two tests of physical characterizations are carried out on the formulated concrete. These are the sag of fresh concrete and density of hardened concrete.

The subsidence test is carried out according to standard NF EN 12350-2 [36]. It consists in measuring the consistency of fresh concrete compacted in a mold having the shape of a truncated cone.

The densities of hardened concrete are evaluated according to standard NF EN 12350-6 [37] and NF EN 12390-7 [38] respectively.

The compressive and tensile strengths of hardened concrete are determined in accordance with standards NF EN 12390-3 [39] and NF EN 12390-6 [40].

\section{Study of the use of palmyra wood and rattan wood in concrete.}

The flexed elements of the reinforced concrete structures are stressed both in compression and in tension. To guarantee the resistance and the stability of these structure, it must have an association of concrete - palmyra / rattan wood. The essential condition of this association is adhesion. This adhesion will allow the transmission of forces and the rational functioning of the reinforced concrete elements.

The calculations leading to the implementation, require knowledge of the physical and mechanical characteristics of laterite concrete, palmyra wood and rattan wood. In addition, it is also necessary to analyze the capacity of palmyra wood and rattan to resist tensile force and shear respectively.

\section{Highlighting of the concrete-palmyra wood adhesion and behaviors at the interface of} two superimposed beams stressed in pure shear

It was a question here of cheching whether there is a tangential connection to the wood-toconcrete interface due to friction and bracing to the concrete conneting rods. This test consisted in exerting a pull-out force along the axis of the test pieces of the palmyra wood anchored in a 
concrete block $110 \mathrm{~mm}$ in diameter and $220 \mathrm{~mm}$ in length. The anchoring length of the bar is taken to be $100 \mathrm{~mm}$.

The maximum pullout force is divided by the lateral surface of the rebar in contact with the concrete so as to obtain the maximum apparent adhesion stress. This stress is calculated by $\frac{F}{\pi l d}$, where $\mathrm{F}=$ maximum compression force, $\mathrm{l}=$ anchor length and $\mathrm{d}=$ diameter of the reinforcement.

\section{Shear test}

The bending of the elements of the reinforced concrete structures is accompanied by a sliding of the fibers in the longitudinal direction (effect of the tensile and compressive forces) and the transverse direction (effect of the shearing force). In order to avoid longitudinal sliding and cracks, frames and stirrups are necessary. In the present work, these frames and stirrups are made of rattan lianas. The objective of the shear test carried out here, is to observe the impact that the rattan lianas can have on the longitudinal sliding, when one plans to carry out a slab in mixed structure (rib in conventional sand concrete and laterite concrete compressive table) as shown in Fig. 3.

The study of rattan lianas shear resistance is carried out, according to the prescriptions of standard EN 26891 [41]. The tests were carried out on symmetrical test pieces (Fig. 6) in order to eliminate the bending effect at the interface of the test piece. Three types of test pieces were tested: a first type consists of test pieces without connection; a second consisting of test pieces with connection (one rattan liana of $12 \mathrm{~cm}$ in length and diameter varying from $11 \mathrm{~mm}$ to 12.5 $\mathrm{mm}$ ); a third consisting of test pieces with connection but this time with two rattan lianas of 12 $\mathrm{cm}$ in length and diameter varing from 11 to $12.5 \mathrm{~mm}$. Figure 6 shows the configuration of the test pieces.
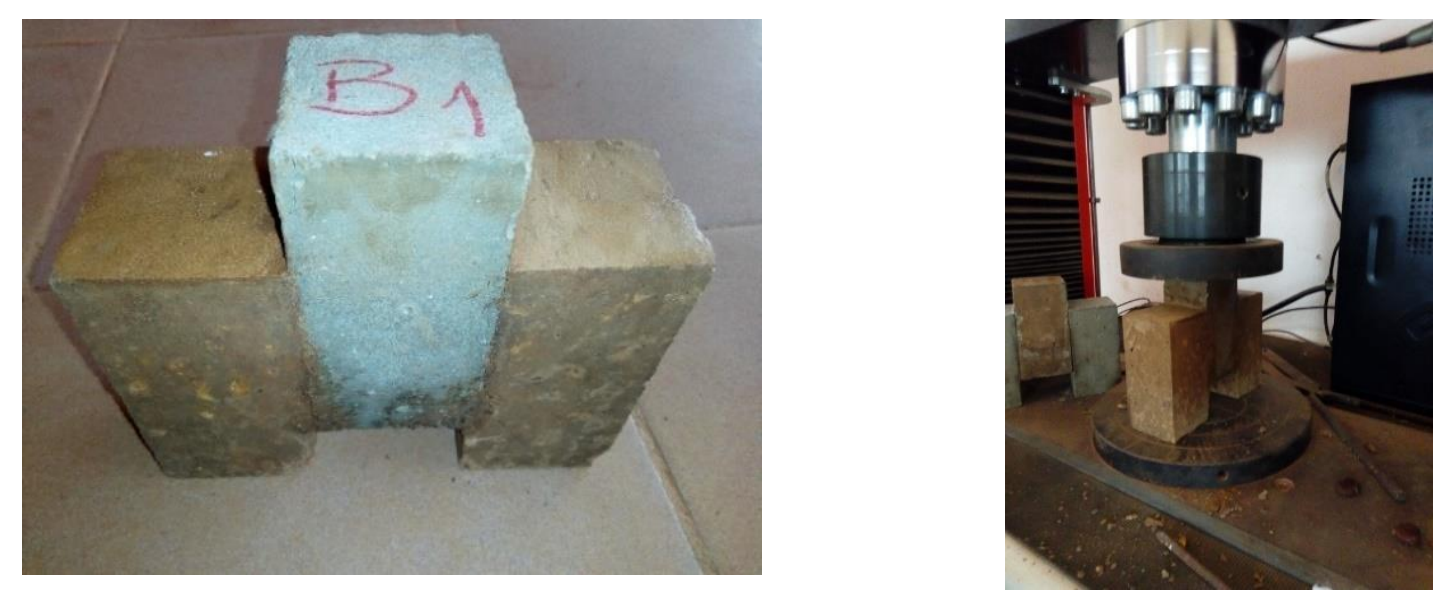
Fig. 6 Device for sliding the interface between sand concrete and laterite concrete

\section{Applicability of palmyra wood, rattan wood and laterite concrete materials in the production of hollow body slab}

In order to prove the effectiveness and efficiency of the palmyra, rattan and laterite concrete reinforcements in the hollow-body slab of social housing, a dimensioning of the compressive table and the rib is made. In order to validate the reinforcement of slab, an analytical and numerical study of the deformation state of said slab are carried out. Fig. 7 shows the slab structure.

The analytical and numerical calculation of the deformation of the slab is made following the homogenization and modeling of the rib. Homogenization is done according to the principle of the law of mixtures applied to mechanical characteristics for stresses parallel to the fibers. Thus the volume fractions, the equivalent Young's modulus and the equivalent Poisson coefficients for the compressive table and the rib are calculated. The modeling is done, considering that the interjoists in the hollow body slab are filling elements and do not participate in the flexural behavior of the slab. The analytical simulation of the behavior of the rib in bending is examined by the method of the resistance of materials. The conduct of the numerical simulation was possible thanks to the use of a computer with "ABAQUS / CAE 6.14-15" software.

Numerical modeling is based on Finite Element analysis. It was an implicit calculation code whose calculation algorithm is based on iterative calculations. The mesh used is of the very tight type. The calculated rib is simply supported on its two ends and stressed in bending by a uniform load. 


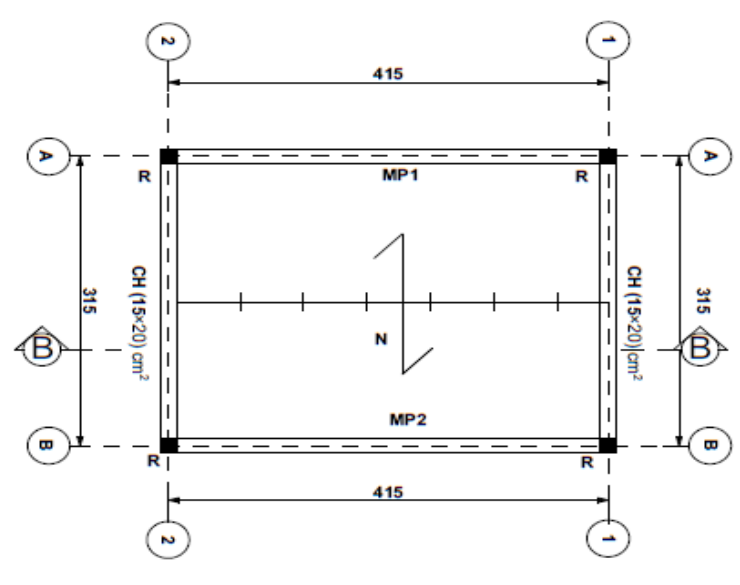

a

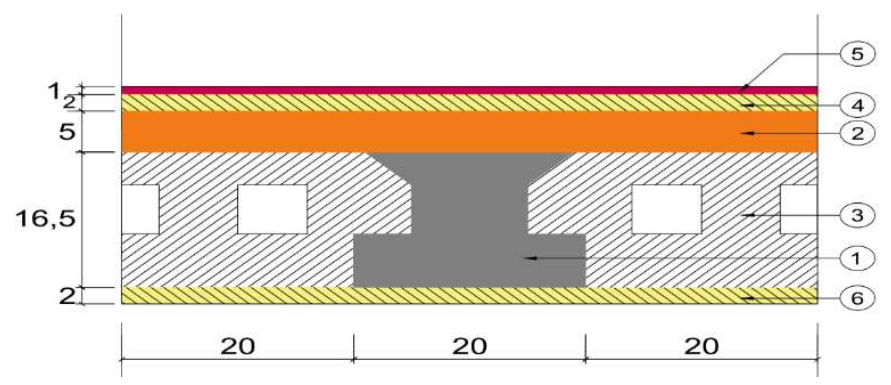

1: Normal concrete rib ; 2: Laterite concrete compressive table; 3 : Rice husks interjoists; 4 : Slope shape; 5 : Multilayer waterproofing; 6 : Plaster under slab

b

Fig. 7 Slab structure plan. a Beam plan; b Section BB

As palmyra wood and rattan wood are not corrosive materials, the dimensions of the ribs and the compressive table are only made in the ultimate limit state. The reinforcements are in circular section.

The assumptions and principle of calculation (dimensioning) of the ribs and of the compressive table used, are those recommended by BAEL 91 modified 99 (Article B.6.8.42) [42]. The density of the constituent elements of the slab (fig. 6b) and the operating load are taken in accordance with standard NF EN 1991-1-1 [43]. However, taking into account the nature of the reinforcements (fibrous materials) and concrete (lateritic gravelly earth) used, the values of density, characteristic compressive and tensile strengths of concrete at 28 days, elastic limits and modulus of elasticity are calculated or determined from the characterization tests. On the other hand, the density of the interjoists in rice hulls and the safety coefficient of the longitudinal and transverse reinforcements are $12 \mathrm{kN} / \mathrm{m}^{3}[12]$ and 2 .

The analytical and numerical calculation of the slab is done by analyzing the behavior of its homogenized rib whose simplified model is presented in Fig. 8. The equivalent elastic characteteristics of the slab were calculated on the basis of the data in the Table 2 [44].

This rib is simply supported on its two ends and stressed in simple bending. The width of the table taken up by the rib: by $=0.60 \mathrm{~m}$; the span of the ribs: $b_{x}=3.15 \mathrm{~m}$; the thickness of the table: $\mathrm{t}=0.05 \mathrm{~m}$; the thickness of the rib: $\mathrm{t}_{\mathrm{x}}=0.10 \mathrm{~m}$; the height of the rib: $\mathrm{h}_{\mathrm{x}}=0.165 \mathrm{~m}$; the position of the center of inertia of the rib relative to the average sheet of the table: $e_{x}=0.1075$ $\mathrm{m}$; the floor height: $\mathrm{h}=0.215 \mathrm{~m}$. 
Table 2 Elastic characteristics of constituent materials of the slab [44]

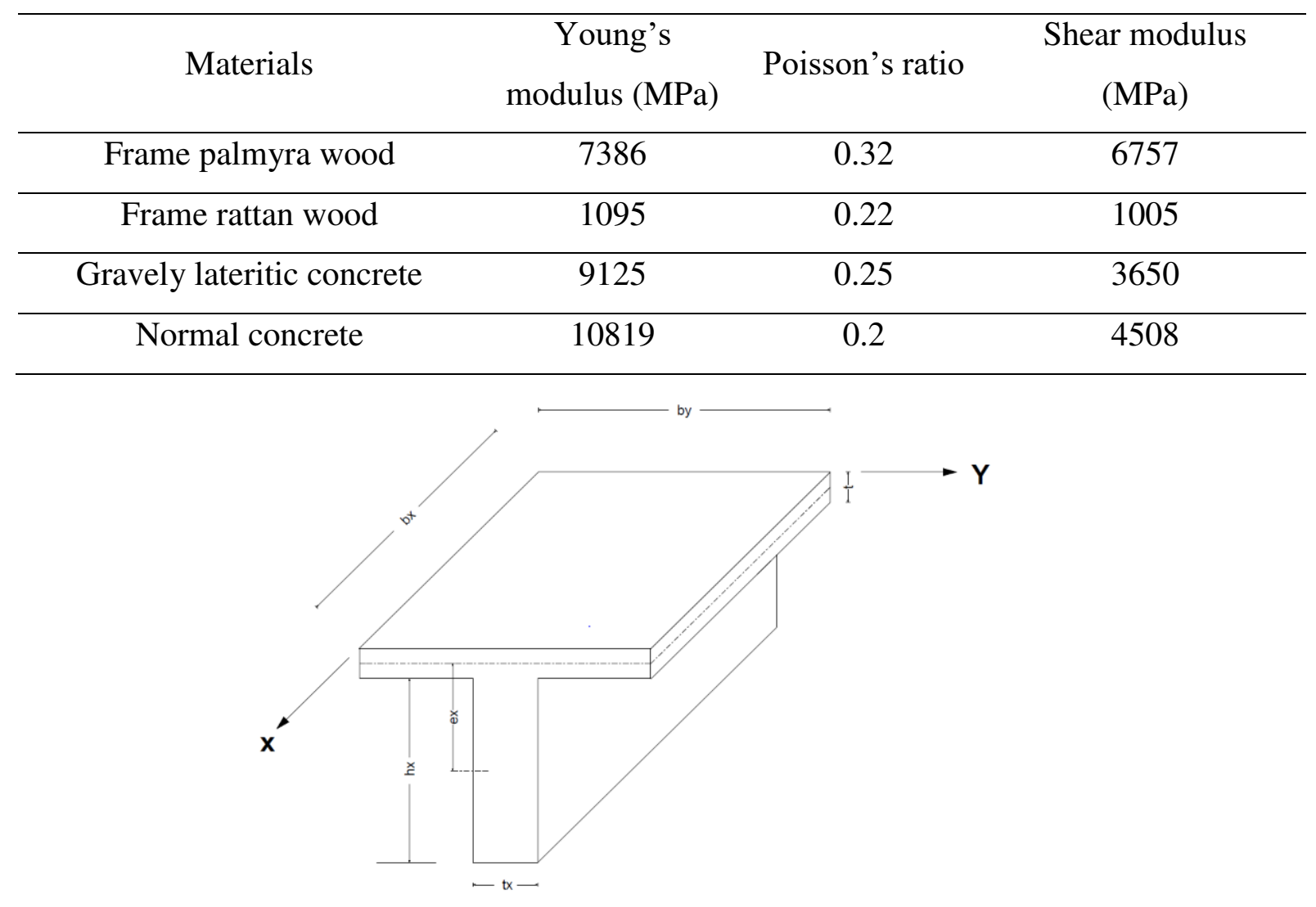

Fig. 8 Simplified rib model

The calculation assumptions are as follows:

- The angular deformations on this plate remain zero;

- The deformation $\epsilon_{z}$ is neglected;

- The thickness of the table is small $(\mathrm{t}=5 \mathrm{~cm})$; consequently, the stresses in the thickness direction are assumed to be zero;

- The stress state being plane, we have $\tau_{\mathrm{yz}}=\tau_{\mathrm{xz}}=0$

The deformation of the slab is calculated by the expression:

$$
w(x)=\frac{p x}{24 E I}\left[l^{3}-2 l x^{2}-x^{3}\right]
$$

With, $\quad 0 \leq x \leq l$

Where, $p$ is taken equal to the value of the action in the service limit state $\left(\mathrm{N}_{\text {ser }}=\mathrm{G}+\mathrm{Q}\right.$, here, $\mathrm{G}=$ permanent $\operatorname{load}(\mathrm{N} / \mathrm{mm})$ and $\mathrm{Q}=$ exploitation load $(\mathrm{N} / \mathrm{mm})), E=$ equivalent elastic modulus 
of rib (MPa), I = moment of inertie of the T-section of the rib $\left(\mathrm{mm}^{4}\right), l=$ span of T-beam $(\mathrm{mm})$ .The maximum deflection at the center of slab is calculated using the expression:

$$
w_{0 \max }=\frac{5 P l^{4}}{384 E I}
$$

\section{Results and discussion}

\section{Absorption kinetics of palmyra and rattan woods}

Fig. 9 shows the ability of rattan and palmyra woods to allow water to enter and circulate through its cells. We observe that the palmyra wood absorbs water less quickly than the rattan wood. The average saturation point of rattan wood of about $172 \%$ is reached at around 6 days, while the palmyra wood has an average saturation point of $64 \%$. It's reached at around 23 days. So these two materials subjected to humidity conditions become hygroscopic. Thus in fresh concrete, not only could they modify the quantity of mixing water but also undergo a significant swelling followed by a shrinkage (Table 2) when the concrete hardens. This dimensional instability could cause the adhesion to break between them and the concrete. To overcome this, it is necessary to waterproof them before associating them with fresh concrete.

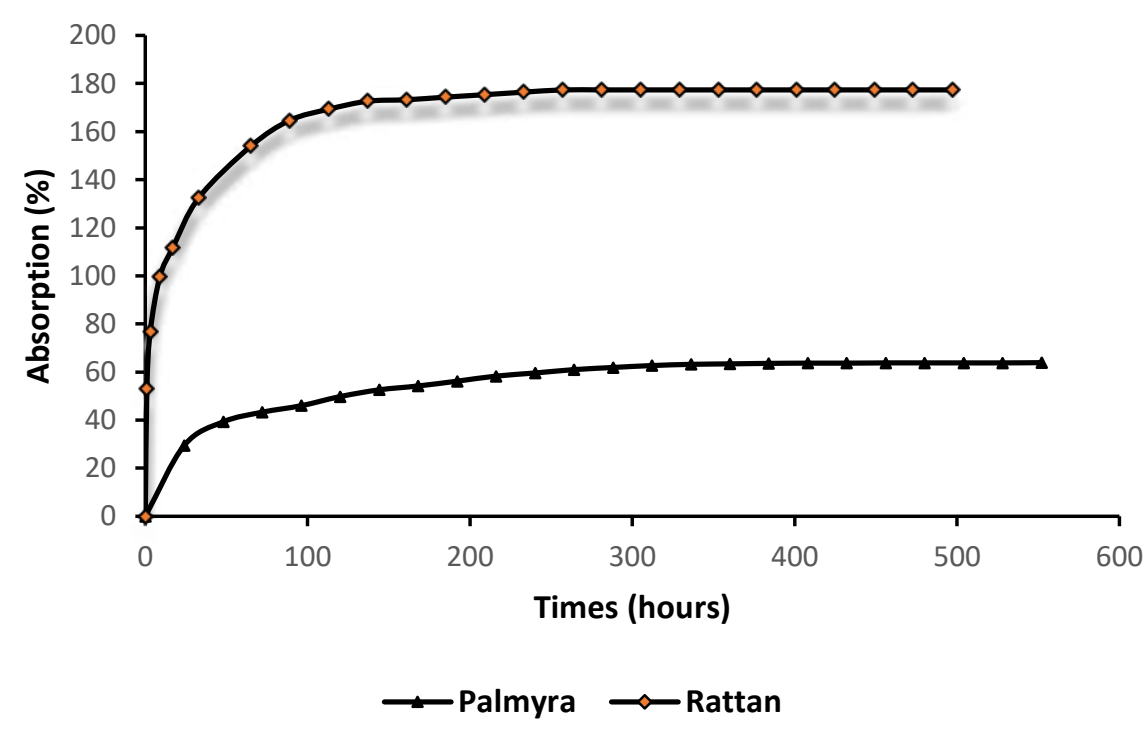

Fig. 9 Kinematics of absorption of specimens from the palmyra and rattan woods

\section{Behavior and mechanical caracteristics in traction of palmyra and rattan woods}

The laws of tensile behavior of the palmyra wood and the rattan wood are represented on Fig. 10 and Fig. 11. These curves show that the rattan wood has elastoplastic behavior while the 
palmyra wood has brittle behavior. However, for the two cases of stresses, we note that the palmyra wood presents a fragile behavior, while the rattan wood a ductile behavior.

Generally, hard and dense woods have brittle tensile behavior, unlike soft and soft woods with low density are ductile.

Generally, hard and dense woods have brittle tensile behavior, unlike soft and soft woods with low density are ductile. Therefore, the analysis of the two curves of mechanical behavior shows us this evidence, because the palm tree wood has a density included in 700 and $800 \mathrm{~kg} / \mathrm{m}^{3}$ therefore hard, and the rattan wood a density lower than $450 \mathrm{~kg} / \mathrm{m}^{3}$ therefore soft

The physical and mechanical properties of the palm and rattan woods calculated are presented in Table 3. In this table we designate by: $\mathrm{H}$ - humidity rate, $\mathrm{M}_{\mathrm{v}}$ - basal density, $\mathrm{G}_{\mathrm{v}}$ - volumic swelling, $\mathrm{R}_{\mathrm{v}}$ - volumic shrinkage, $\mathrm{E}$ - modulus of elasticity, $\sigma_{\mathrm{r}}$ - rupture stress, $f_{e}$ - elastic limit.

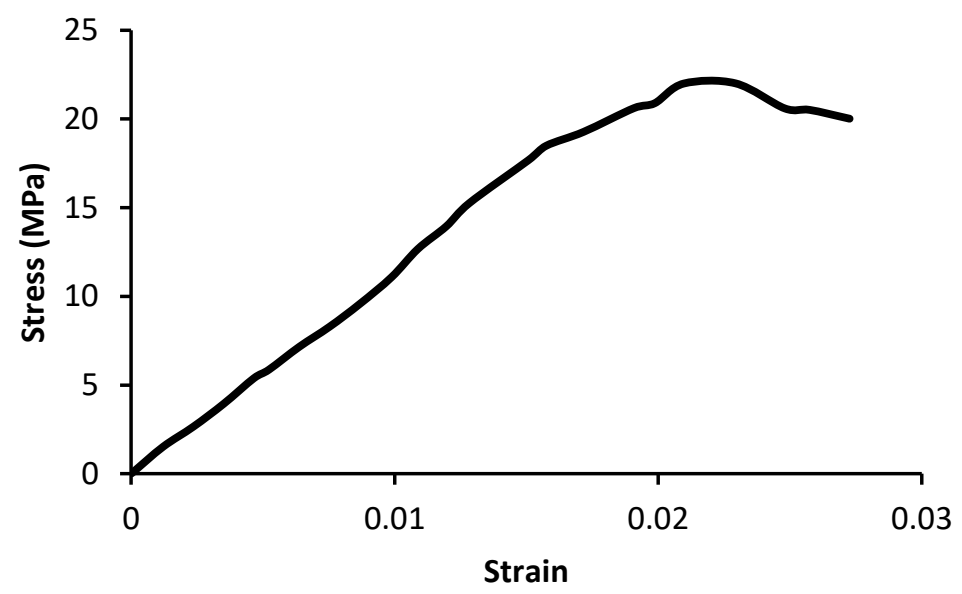

Fig. 10 Stress-strain curve of the rattan wood in tension 


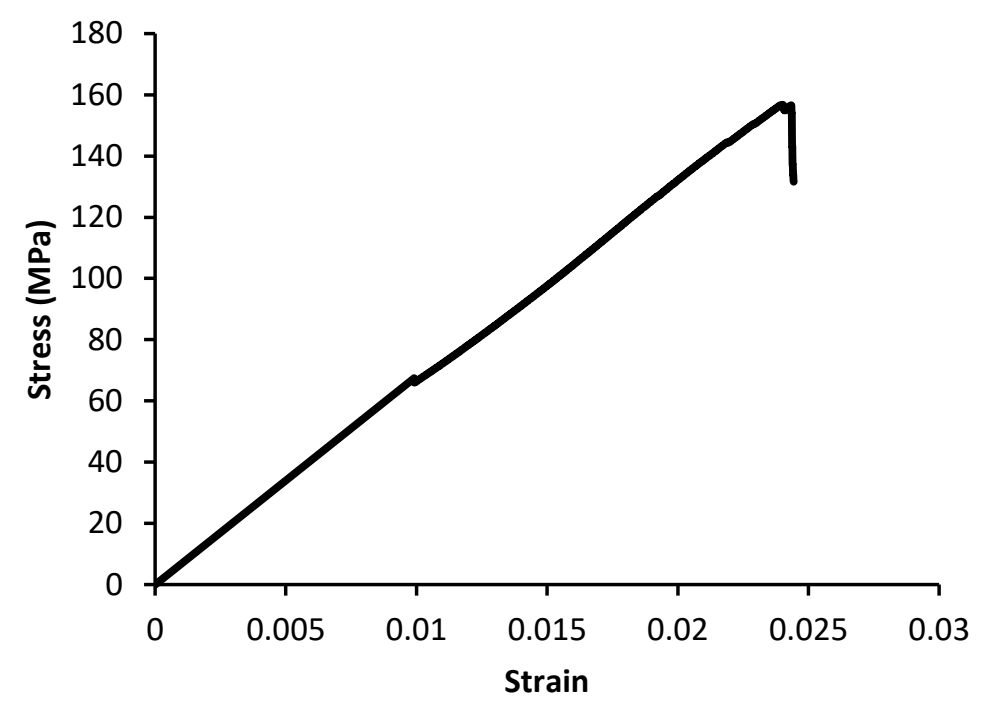

Fig. 11 Stress-strain curve of the Palmyra wood in tension

Table 3 Physical and mechanical properties of the palmyra and rattan woods

\begin{tabular}{cccccccc}
\hline & \multicolumn{3}{c}{ Physical properties } & \multicolumn{3}{c}{ Mecanical properties } \\
\cline { 2 - 8 } Materials & $\mathrm{H}$ & $\mathrm{Mv}$ & $\mathrm{R}_{\mathrm{v}}$ & $\mathrm{G}_{\mathrm{v}}$ & $\mathrm{E}$ & $\sigma_{\mathrm{r}}$ & $f_{\mathrm{e}}$ \\
& $(\%)$ & $\left(\mathrm{g} / \mathrm{cm}^{3}\right)$ & $(\%)$ & $(\%)$ & $(\mathrm{MPa})$ & $(\mathrm{MPa})$ & $(\mathrm{MPa})$ \\
\hline $\begin{array}{c}\text { Pamyra } \\
\text { wood }\end{array}$ & 15 & 0.715 & 15 & 16 & $7386.7 \pm 187.36$ & $156.08 \pm 18.21$ & $156.08 \pm 13.28$ \\
\hline Rattan wood & 13 & 0.351 & 18 & 23 & $1095.3 \pm 74.85$ & $22.01 \pm 3.00$ & $22.01 \pm 1.00$ \\
\hline
\end{tabular}

\section{Caracteristics formuled laterite concretes}

The laterite concretes formulated with a cement $400 \mathrm{~kg} / \mathrm{m}^{3}$ have the following characteristics at 28 days (Table 4$)$ :

- $\quad$ density $\left(\mathrm{M}_{\mathrm{v}}\right)$ between 21.5 to $22.3 \mathrm{kN} / \mathrm{m}^{3}$;

- compressive strength $\left(\mathrm{R}_{\mathrm{c}}\right)$ between 10.85 and $21.23 \mathrm{MPa}$;

- tensile strength $\left(\mathrm{R}_{\mathrm{t}}\right)$ between 1.13 and $1.87 \mathrm{MPa}$.

According to the general principles of reinforced concrete constructions [45], concrete can withstand compressive strength from 15 to $60 \mathrm{MPa}$. Statrting from this technolocal 
recommendation and taking a look at table 3 , it is obvious, that the optimal formulation is that which $\mathrm{k}_{\mathrm{e}}=0.4$ and $\mathrm{k}_{\mathrm{n}}=2.8$. However, this concrete has a consistency (sag) equal to $2 \mathrm{~cm}$. In this case, a powerful vibration is needed for its implementation.

Table 4 Densities and mechanical strengths at 28 days of the different formulated laterite concretes

\begin{tabular}{|c|c|c|c|c|c|c|c|c|}
\hline \multirow{2}{*}{$\begin{array}{l}\text { Caracteristics } \\
\text { of formuled } \\
\text { concrete }\end{array}$} & \multicolumn{3}{|c|}{$\mathrm{k}_{\mathrm{n} 2,2}$} & \multicolumn{3}{|c|}{$\mathrm{k}_{\mathrm{n} 2,5}$} & \multicolumn{2}{|r|}{$\mathrm{k}_{\mathrm{n} 2,8}$} \\
\hline & $\begin{array}{c}\mathrm{Mv} \\
\left(\mathrm{KN} / \mathrm{m}^{3}\right)\end{array}$ & $\begin{array}{c}\mathrm{Rc} \\
(\mathrm{MPa})\end{array}$ & $\begin{array}{c}\mathrm{Rt} \\
(\mathrm{MPa})\end{array}$ & $\begin{array}{c}\mathrm{Mv} \\
\left(\mathrm{KN} / \mathrm{m}^{3}\right)\end{array}$ & $\begin{array}{c}\mathrm{Rc} \\
(\mathrm{MPa})\end{array}$ & $\begin{array}{c}\mathrm{Rt} \\
(\mathrm{MPa})\end{array}$ & $\begin{array}{c}\mathrm{Mv} \\
\left(\mathrm{KN} / \mathrm{m}^{3}\right)\end{array}$ & $\begin{array}{c}\mathrm{Rc} \\
(\mathrm{MPa})\end{array}$ \\
\hline $\mathrm{k}_{\mathrm{e} 0,4}$ & $2167.8 \pm 47.01$ & $14.64 \pm 1.42$ & $1.13 \pm 0.39$ & $2218.07 \pm 19,48$ & $13.46 \pm 1,37$ & $1.37 \pm 0.19$ & $2230.02 \pm 61.65$ & $21.23 \pm 1.24$ \\
\hline $\mathrm{k}_{\mathrm{e} 0,5}$ & $2126.68 \pm 12.73$ & $16.81 \pm 1.8$ & $1.25 \pm 0.1$ & $2169.00 \pm 11.13$ & $13.81 \pm 1.18$ & $1.26 \pm 0.07$ & $2156.67 \pm 32.11$ & $17.26 \pm 1.65$ \\
\hline $\mathrm{k}_{\mathrm{e} 0,6}$ & $2106.95 \pm 19.09$ & $15.79 \pm 0.57$ & $1.2 \pm 0.2$ & $2069.11 \pm 31,77$ & $11.45 \pm 0.88$ & $1.31 \pm 0.33$ & $2140.81 \pm 38.49$ & $16.68 \pm 1.38$ \\
\hline $\mathrm{k}_{\mathrm{e} 0,7}$ & $2052.93 \pm 64.13$ & $10.89 \pm 0.36$ & $1.15 \pm 0.27$ & $2063.9 \pm 53.19$ & $11.06 \pm 0.99$ & $1.22 \pm 0.27$ & $2066.12 \pm 14.17$ & $13.35 \pm 1.25$ \\
\hline
\end{tabular}

\section{Adhesion stress of palmyra wood frames}

Highlighting the association of palmyra wood-concrete made through concrete-palmyra wood adhesion tests shows that the palmyra wood adheres perfectly to concrete. The quality of this adhesion improves when the surface of the wood has crenels. In fact, the pull-out strenght of smooth and crenellated reinforcements are respectively 2.77 $\mathrm{MPa}$ and 3.68 $\mathrm{MPa}$.

\section{Influence of rattan lianas on the sliding of the interface of superimposed mixed concrete} blocks (normal concrete and laterite concrete)

The study of the sliding of the normal concrete-lateritic concrete interface with and without rattan connection reinforcement by push-out tests (Fig. 6) reveals, that the presence of rattan lianas opposes slippage of interface of the concrete blocks. For this purpose, we have observed that:

- the rupture of the connections whose interfaces are not provides with reinforcements occurred by a premature separation of the concrete blocks. This rupture is rapid and abrupt. Any deformation is not observed on the concrete blocks;

- the interface connections provided with a single reinforcement rupture by a gradual separation of the concrete blocks and very often accompanied by the plasticization of rattan lianas. The concrete blocks are always connected to the connector rod. Any deformation is not observed on the concrete blocks; 
- the longitudinal sliding of the interfaces provided with two reinforcements causes cracking of the concrete blocks in the vicinity of the connector reinforcements.

In view of all of the foregoing, the laterite concrete, the palmyra and rattan woods can be used in the production of slab structures as show in the Fig. 3. However, these slabs must be lightly loaded, in view of the fact that the elastic limit and the breaking stress of the palmyra wood are low than those of the steels recommendes for reinforced concrete.

\section{Effectiveness of rattan and Palmyra woods as reinforcement of hollow body slabs}

It follows from the calculations carried out in accordance with the calculation codes for reinforced concrete structures, the following:

- The diameters of reinforcement of the grid of the compressive table in the directions perpendicular and parallel to the ribs are respectively $10 \mathrm{~mm}$ and $13 \mathrm{~mm}$. Their number (and spacing) are respectively $25(4 \mathrm{~cm})$ and $12(8 \mathrm{~cm})$.

- The diameters of the longitudinal and transverse reinforcements are respectively $18 \mathrm{~mm}$ and $10 \mathrm{~mm}$. Their arrangement, distribution are presented in Fig. 12. The Fig. 13 shows the pratical realization of the reinforcement of the rib.

The maximum arrows from the analytical and numerical studies of the state of deformation in flexion of the rib are respectively $0.39 \mathrm{~cm}$ and $0.42 \mathrm{~cm}$. By comparing these two values, there is only a slight difference. Thus, the calculation model chosen of the rib is suitable for the two calculation methods used. Furthermore, each of the values of the deflection is less than the admissible deflection which is $1.26 \mathrm{~cm}$ (ratio of the span L of the rib to 250). Fig. 14 presents the comparison between the exact deformation and the deformation by numerical simulation, while Fig. 15 shows the state of deformation of the rib / slab.

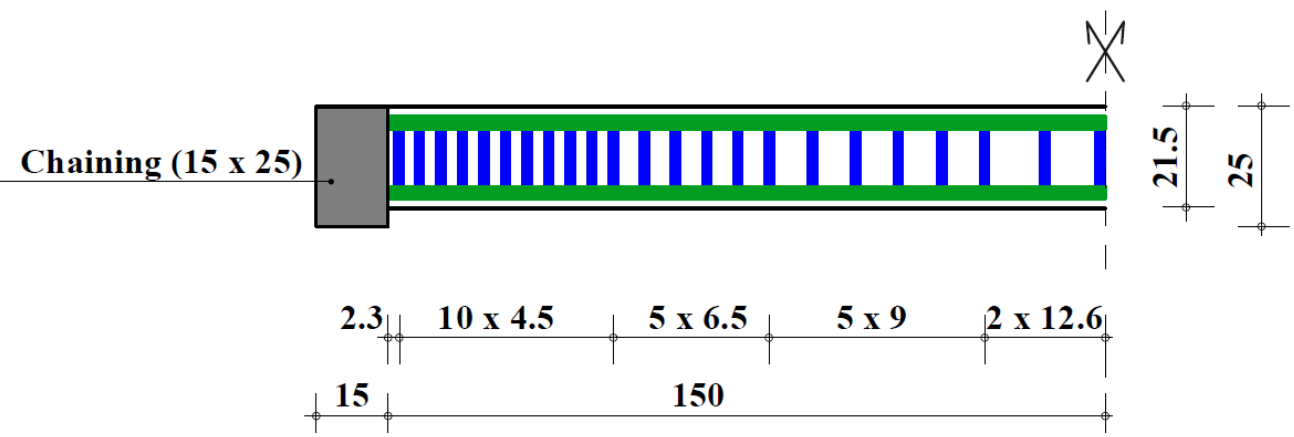

Fig. 12 Distribution of transverse reinforcements on half of the rib 

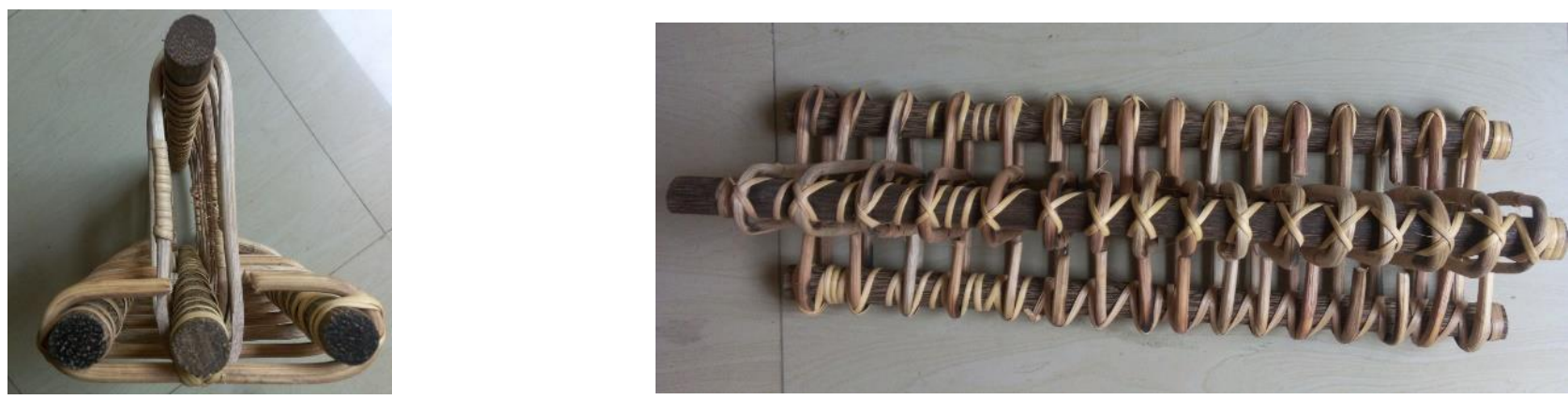

Fig. 13 Rib reinforcement prototype

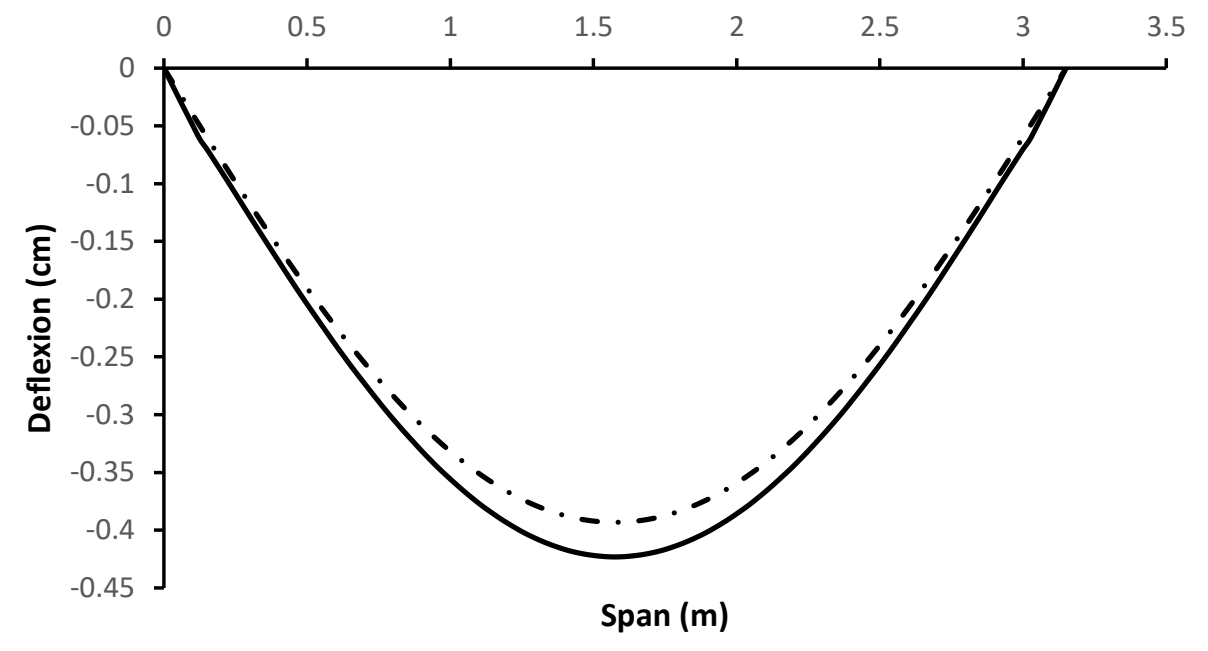

- - Numerical curve $\longrightarrow$ theoretical curve

Fig. 14 Comparative deformations of the rib by analytical and numerical calculations

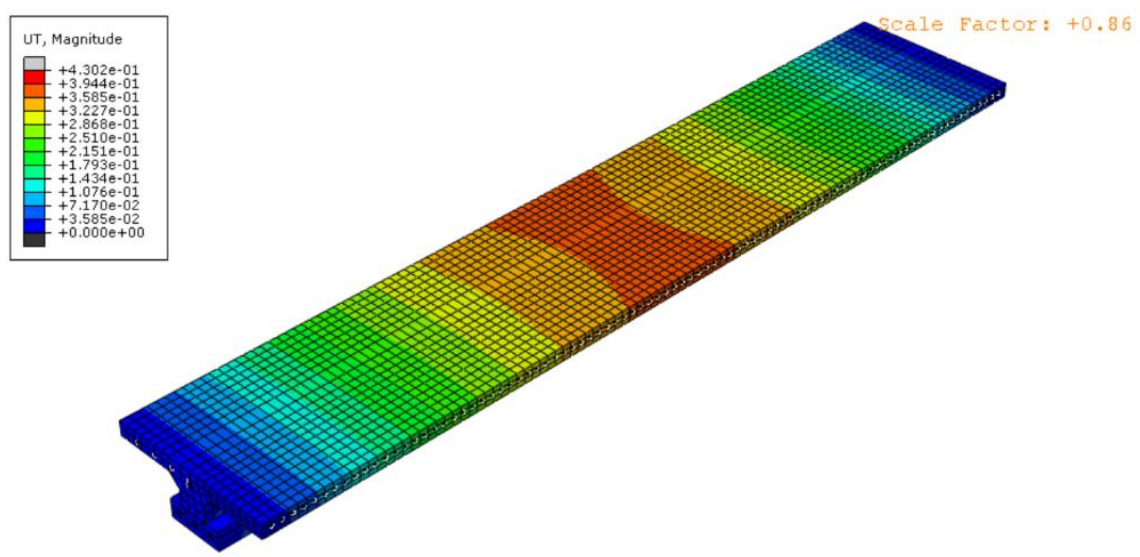

Fig. 15 Rib deformation state mapping 


\section{Conclusion}

The palmyra and the rattan trees are monocots, the wood of which is used in a disproportionate way in the realization of the structures of traditional constructions in lateritic earth. This process does not contribute to the rational use of the shrub plant cover.

With the aim of remedying this state of affairs, the present work is developing a process for valuing palmyra wood, rattan wood and laterite for the realization of the flexed structure of social housing.

Analytical and numerical analyzes of the state of flexural deformation of the rib designed and dimensioned in normal concrete and laterite concrete reinforced with palmyra and rattan woods reinforcements, demonstrate the structural efficiency of concrete, reinforcements in palmyra and rattan woods in modern low-load slabs of social housing in rural towns.

This process brings to the studies previously carried out in the field of building materials the following innovations:

- the behaviors and mechanical characteristics of the frames in palmwood and rattan have been described. These results allowed the use of reinforced concrete calculation code, the modeling and numerical calculation of the ribs of hollow body slabs,

- a method for formulating lateritic gravelly concrete based on the total sum of the absolute volumes of each component plus the volume of entrained air and trapped air corresponding to one cubic meter of concrete has been developed.

- a process for valuing Borassus aethiopum and Calamus deerratus woods and laterite was developed.

\section{References}

1. Raju, N.K., Ramakrishnan, R.: Properties of laterite aggregate concrete. Matér. Constr. 5, 307-314 (1972)

2. Balogun, L.A., Adepegba, D.: Effect of varying sand content in laterized concrete. Int. J. Cem. Compos. Lightweight Concr. 4, 235-240 (1982)

3. Akpokodje, E.G., Hudec, P.: Properties of concretionary laterite gravel concrete. Bull. Int. Assoc. Eng. Geol. - Bull. Assoc. Int. Géologie Ing. 46, 45-50 (1992)

4. Falade, F.: Influence of water/cement ratios and mix proportions on workability and characteristic strength of concrete containing laterite fine aggregate. Build. Environ. 29, 237-240 (1994)

5. Osunade, J.A.: Effect of replacement of lateritic soils with granite fines on the compressive and tensile strengths of laterized concrete. Build. Environ. 37, 491-496 (2002) 
6. Kamaruzaman, N.W., Muthusamy, K.: Engineering Properties of Concrete with Laterite Aggregate as Partial Coarse Aggregate Replacement. Int. J. Civ. Eng. Geo-Environ. (2012)

7. Ephraim, E.M., Adoga, E., Rowland-Lato, O.E.: Strength of Laterite Rock Concrete. Am. J. Civ. Eng. Archit. 4, 54-61 (2016)

8. Souley Issiakou, M.: Caractérisation et valorisation des matérieux latéritiques utilisés en construction routière au Niger, (2016)

9. Ettu, L., Ibearugbulem, M., Ezeh, J.C., Anya, C.U.: The Suitability of Using Laterite as Sole Fine Aggregate in Structural Concrete. Int. J. Sci. Eng. Res. 4, (2013)

10. Ukpata, J., Ephraim, M., Akeke, G.: Compressive strength of concrete using lateritic sand and quarry dust as fine aggregate. ARPN J. Eng. Appl. Sci. 7, (2012)

11. Salau, M.A., Busari, A.O.: Effect of Different Coarse Aggregate Sizes on the Strength Characteristics of Laterized Concrete. IOP Conf. Ser. Mater. Sci. Eng. 96, 012079 (2015)

12. Chabi, E., Doko, V., Hounkpè, S.P., Adjovi, E.C.: Study of cement composites on addition of rice husk. Case Stud. Constr. Mater. 12, e00345 (2020)

13. Chabi, E., Lecomte, A., Adjovi, E.C., Dieye, A., Merlin, A.: Mix design method for plant aggregates concrete: Example of the rice husk. Constr. Build. Mater. 174, 233-243 (2018)

14. Yuzer, N., Cinar, Z., Akoz, F., Biricik, H., Yalcin Gurkan, Y., Kabay, N., Kizilkanat, A.B.: Influence of raw rice husk addition on structure and properties of concrete. Constr. Build. Mater. 44, 54-62 (2013)

15. Sisman, C.B., Gezer, E., Kurc, H.C.: Effects of Rice Husk On The Lighteight Concrete Properties Produced by Natural Zeolite for Agricultural Buildings. Asian J. Appl. Sci. ISSN 2321-0893. 2, (2014)

16. Lima, H.C., Willrich, F.L., Barbosa, N.P., Rosa, M.A., Cunha, B.S.: Durability analysis of bamboo as concrete reinforcement. Mater. Struct. 41, 981-989 (2008)

17. Obilade, O., Olutoge, A.: Flexural Characteristics of Rattan Cane Reinforced Concrete Beams. Int. J. Eng. Sci. 3, 38-42 (2014)

18. Ata, O.: Effects of Varying Curing Age and Water/Cement Ratio on the Elastic Properties of Laterized Concrete. Civ. Eng. Dimens. 9, 85-89 (2007)

19. H.M.A. Mahzuz, Ahmed, M., Uddin, M.K., Hossain, M.M., Saquib, N.: Effectiveness Evaluation of Zali bet as Reinforcement in Concrete Beam. Civ. Eng. Archit. 2, 269-279 (2014)

20. Masani, N.J., Dhamani, B.C., Singh, B.: Studies on Bamboo Concrete Composite Construction. Controller of Publications (1977)

21. Ngouadjeu, P.: Béton de Nodules Latéritiques Armé de Rotin: Contribution à l'amélioration de l'adhérence. ENSP (1992)

22. Gill, S., kumar, R.: To Experimental Study and Use of Bamboo in Civil Structure as Reinforced Concrete. Int. J. Latest Res. Sci. Technol. 5, 102-105 (2016)

23. Adewuyi, A.P., Otukoya, A.A., Olaniyi, O.A., Olafusi, O.S.: Comparative Studies of Steel, Bamboo and Rattan as Reinforcing Bars in Concrete: Tensile and Flexural Characteristics. Open J. Civ. Eng. 05, 228 (2015) 
24. Diallo, M.: Le comportement du rônier (Borassus aethiopum) dans les rôneraies paysannes des régions de Fatick et de Thiès (Sénégal). Ecole des Gradués de l'Université de Laval, Canada (1987)

25. Kosarimovahhed, M., Toufigh, V.: Sustainable usage of waste materials as stabilizer in rammed earth structures. J. Clean. Prod. 277, 123279 (2020). https://doi.org/10.1016/j.jclepro.2020.123279

26. Ajouguim, S., Talibi, S., Djelal-Dantec, C., Hajjou, H., Waqif, M., Stefanidou, M., Saadi, L.: Effect of Alfa fibers on the mechanical and thermal properties of compacted earth bricks. Mater. Today Proc. (2020). https://doi.org/10.1016/j.matpr.2020.07.539

27. Zare, P., Sheikhi Narani, S., Abbaspour, M., Fahimifar, A., Mir Mohammad Hosseini, S.M., Zare, P.: Experimental investigation of non-stabilized and cement-stabilized rammed earth reinforcement by Waste Tire Textile Fibers (WTTFs). Constr. Build. Mater. 260, 120432 (2020). https://doi.org/10.1016/j.conbuildmat.2020.120432

28. Meybodian, H., Eslami, A., Morshed, R.: Sustainable lateral strengthening of traditional adobe walls using natural reinforcements. Constr. Build. Mater. 260, 119892 (2020)

29. Ige, O., Danso, H.: Physico-mechanical and thermal gravimetric analysis of adobe masonry units reinforced with plantain pseudo-stem fibres for sustainable construction. Constr. Build. Mater. 273, 121686 https://doi.org/10.1016/j.conbuildmat.2020.121686

30. NF B 51-004. Bois, Détermination de l'humidité. AFNOR (1985)

31. NF B51-005. Bois - Détermination de la masse volumique. (1985)

32. NF EN 1097-6 Essais pour déterminer les caractéristiques mécaniques et physiques des granulats - Partie 6: Détermination de la masse volumique réelle et du coefficient d'absorption d'eau. AFNOR. 56 (2014)

33. NF B51-006. Bois - Détermination du retrait. (1985)

34. NF B51-017. Bois - Traction parallèle aux fibres - Détermination de la résistance à la rupture en traction parallèle au fil du bois de petites éprouvettes sans défaut. AFNOR (1988)

35. NF B51-018. Bois - Traction parallèle aux fibres - Détermination du module d'élasticité en traction parallèle au fil du bois de petites éprouvettes sans défaut. AFNOR (1988)

36. NF EN 12350-2. Essais pour béton frais - Partie 2 : essai d'affaissement. AFNOR (2019)

37. NF EN 12350-6. Essais pour béton frais - Partie 6 : masse volumique. AFNOR (2019)

38. NF EN 12390-7. Essais pour béton durci - Partie $7:$ masse volumique du béton durci Essais pour béton durci - Partie 7 : Masse volumique du béton durci. AFNOR (2019)

39. NF EN 12390-3. Essais pour béton durci - Partie 3 : résistance à la compression des éprouvettes - Essais pour béton durci - Partie 3: Résistance à la compression des éprouvettes. AFNOR (2019)

40. NF EN 12390-6. Essais pour béton durci - Partie 6: détermination de la résistance en traction par fendage d'éprouvettes. AFNOR (2012)

41. NF EN 26891. Structures en bois - Assemblages réalisés avec des éléments mécaniques de fixation - Principes généraux pour la détermination des caractéristiques de résistance et de déformation. AFNOR (1991) 
42. Perchat, J., Roux, J.: Pratique du BAEL 91: cours avec exercices corrigés. Eyrolles (1999)

43. NF EN 1991-1-1. Eurocode 1 - Actions sur les structures - Partie 1-1 : actions générales Poids volumiques, poids propres, charges d'exploitation des bâtiments. AFNOR (2003)

44. Kakpo, E.A.: Etude du comportement en flexion simple d'un plancher mixte armé de rônier et de rotin: analyse numérique et simulation. École Polytechnique d'AbomeyCalavi (2016)

45. Renaud, H., Letertre, F.: Technologie du bâtiment: Gros-oeuvre. Editions Foucher (1978) 


\section{Figures}

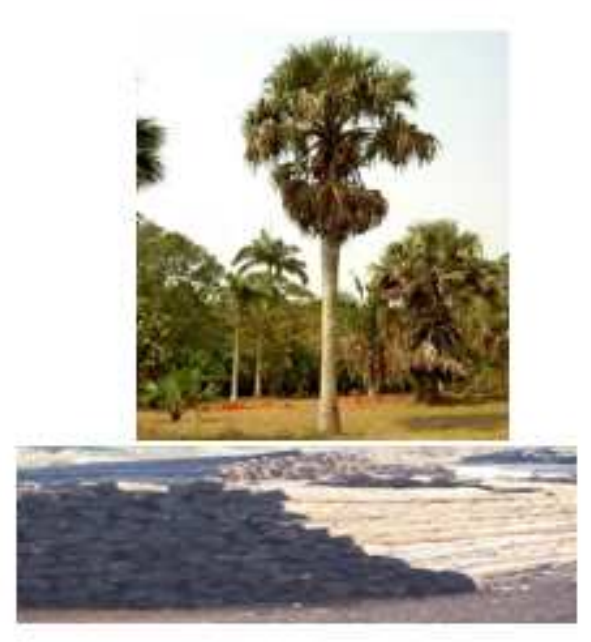

a

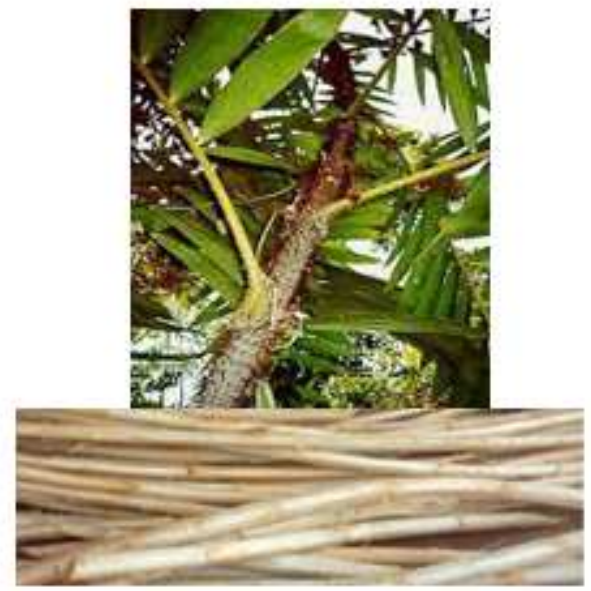

b

Figure 1

a Borassus aethiopum (palmyra wood slats); b Calamus deerratus (rattan lianas)

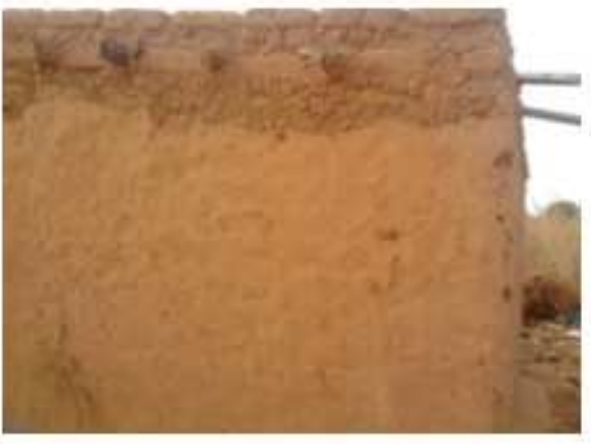

a

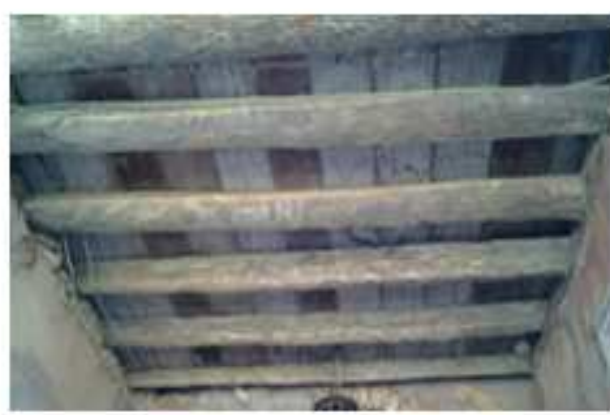

b

Figure 2

a Rural housing in a locality in Niger / West Africa; b Palmyra wood-laterite slab on the Island of Goree / Senegal 


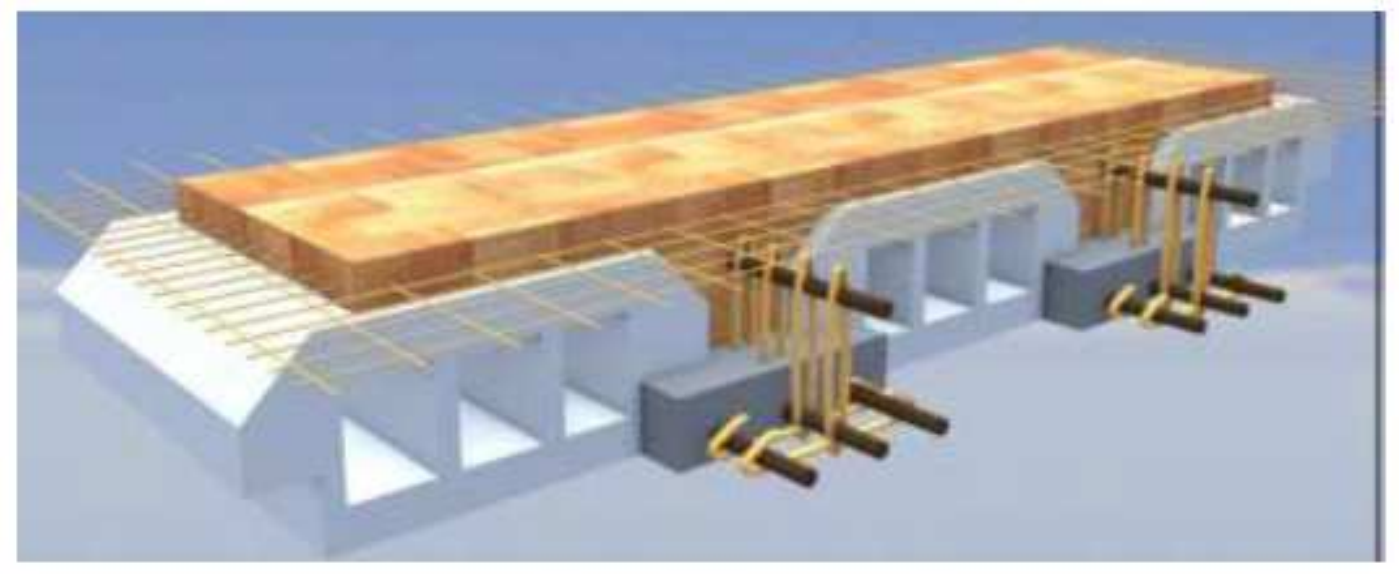

\section{Figure 3}

Model of hollow-body slab made of latérite concrete, lagoon sand concrete, palmyra and rattan reinforcements and interjoists in rice husks

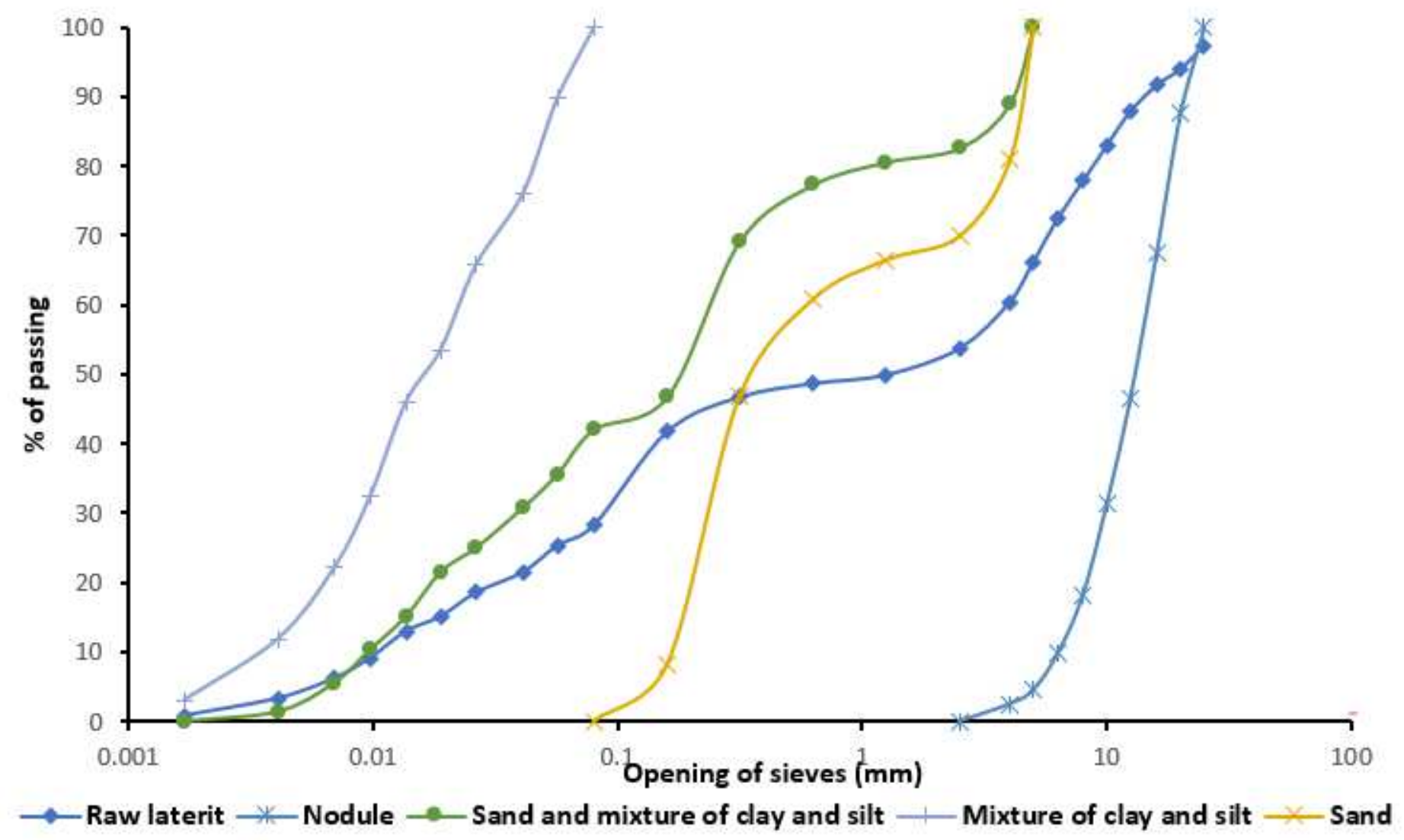

\section{Figure 4}

Granulometry curves of raw laterite and of the granular classes used 


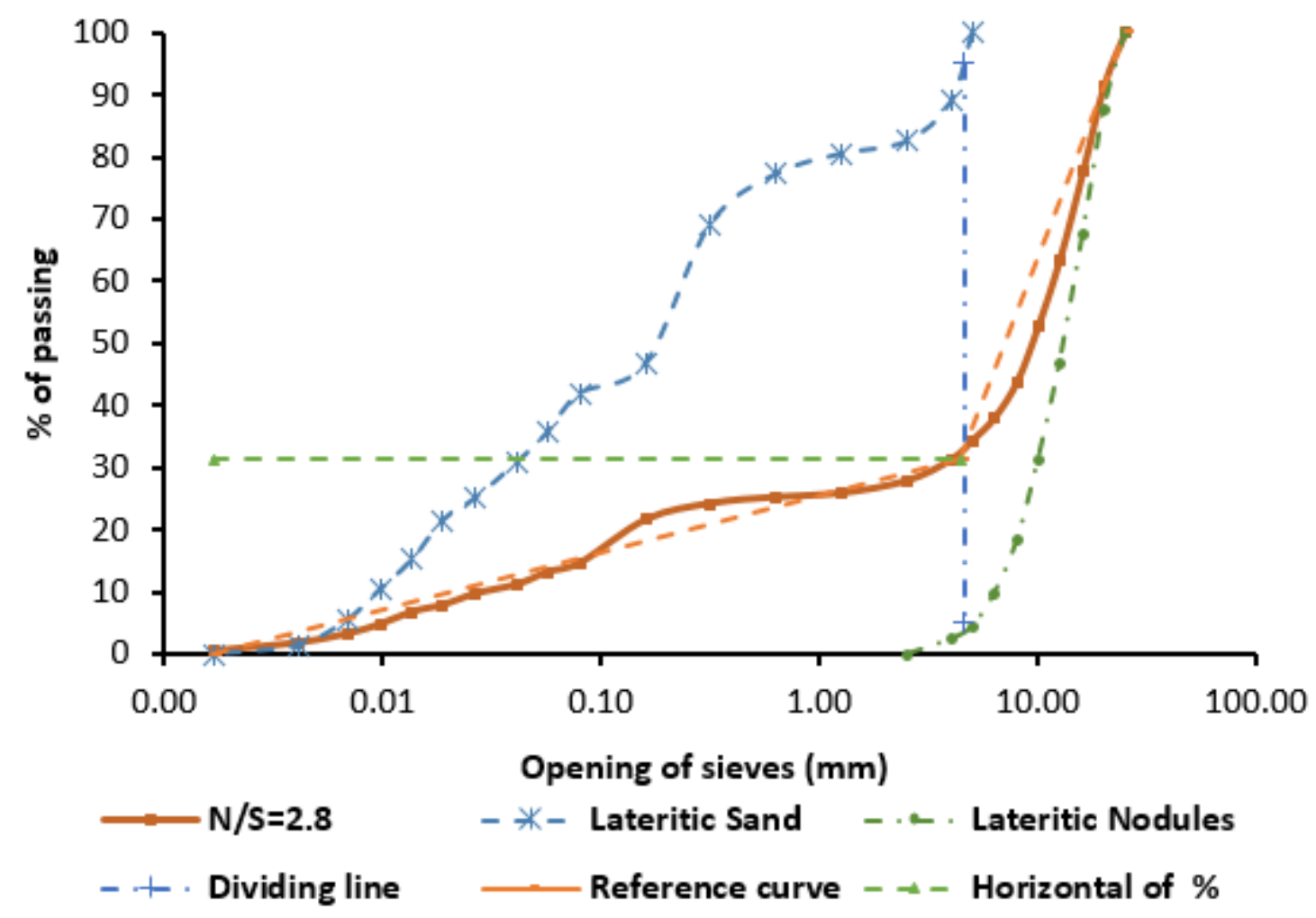

Figure 5

Granulometric curve of the granular composition of sand and nodules lateritic (N/S = 2.8)
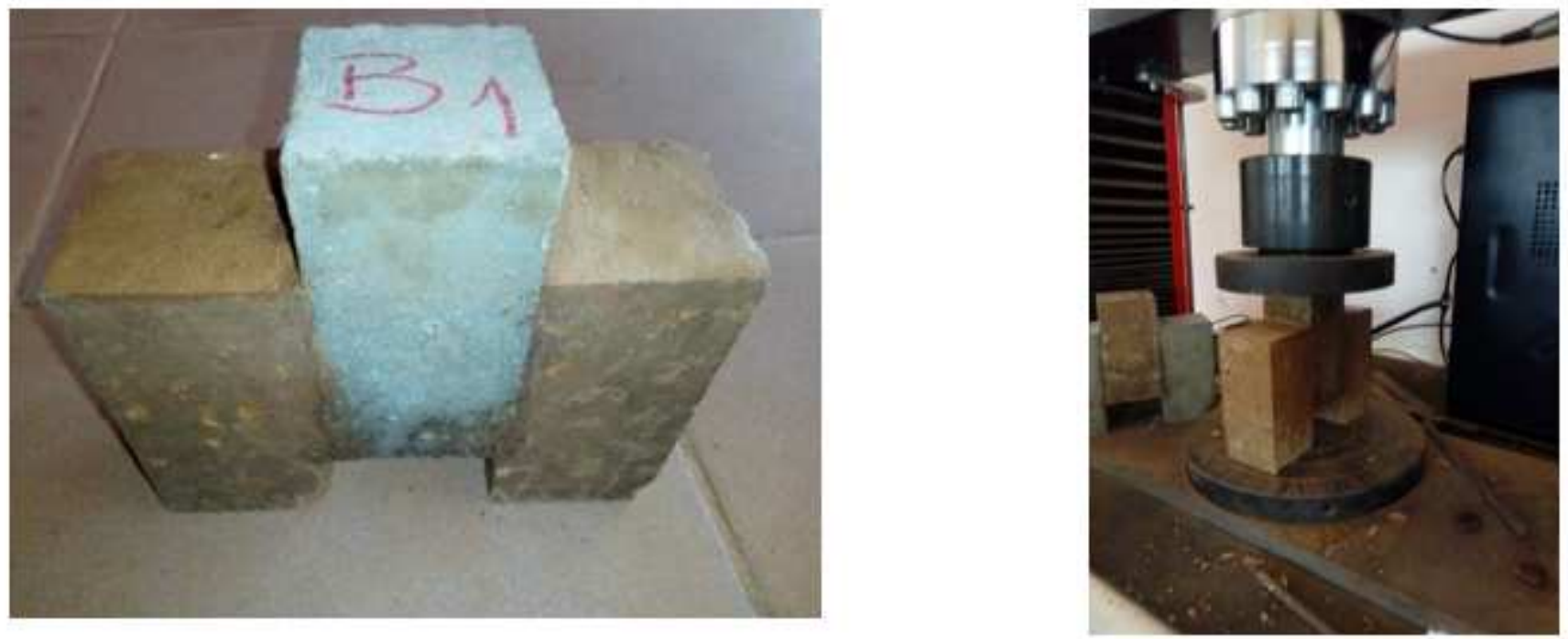

Figure 6

Device for sliding the interface between sand concrete and laterite concrete 


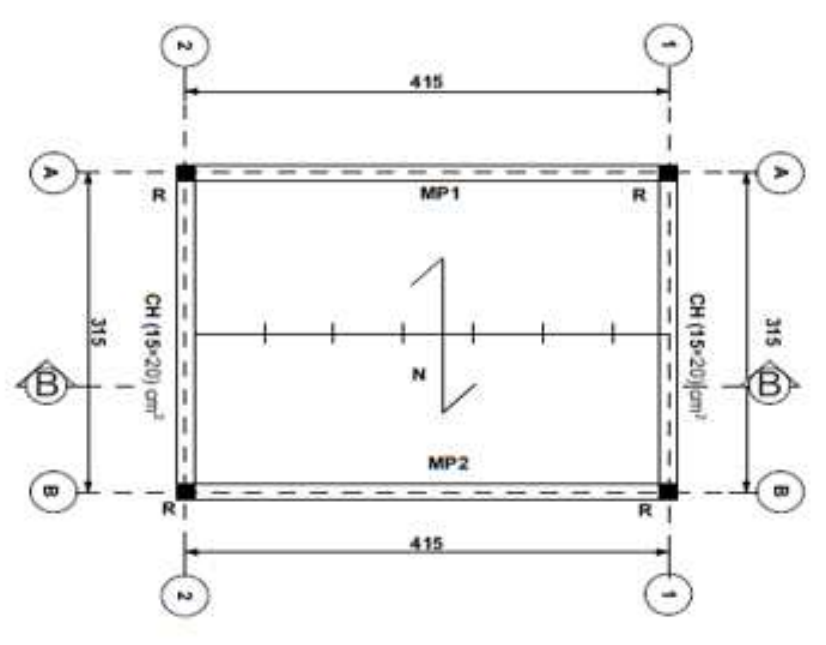

a

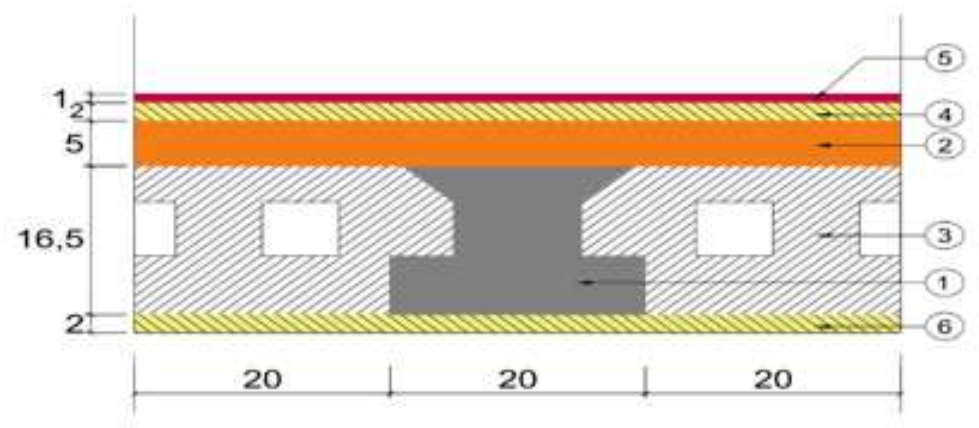

1: Normal concrete rib ; 2: Laterite concrete compressive table; 3 : Rice husks interjoists; 4 : Slope shape; $5:$ Multilayer waterproofing; $6:$ Plaster under slab

\section{Figure 7}

Slab structure plan. a Beam plan; b Section BB

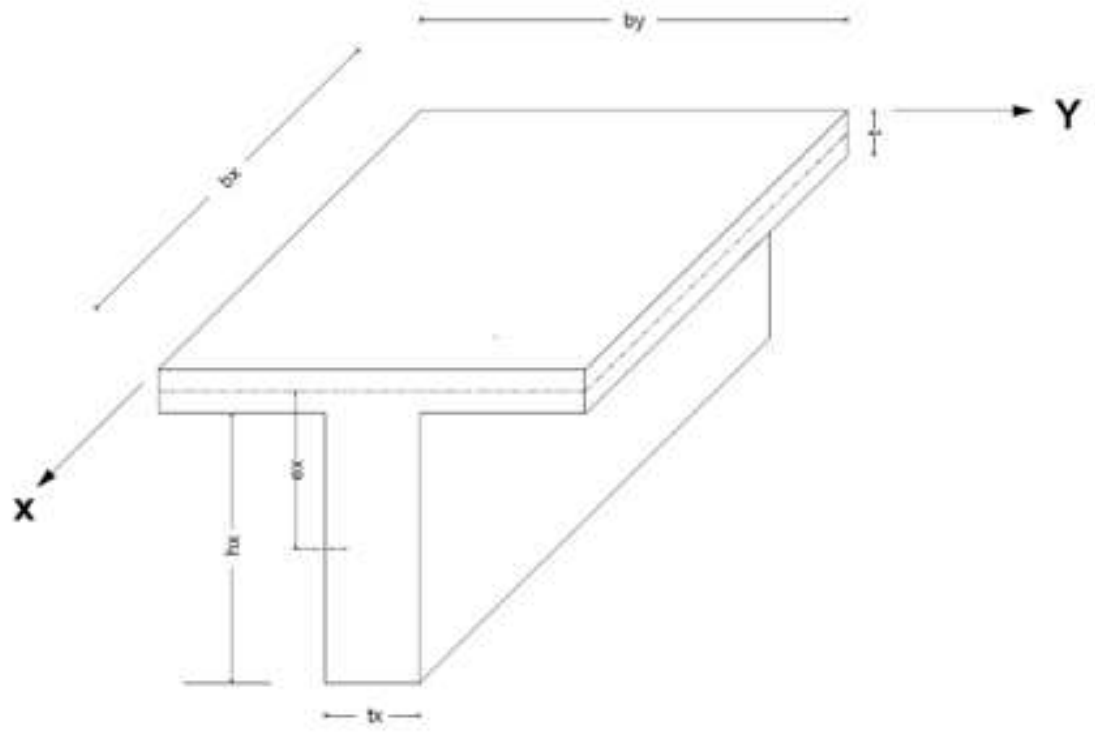

\section{Figure 8}

Simplified rib model 


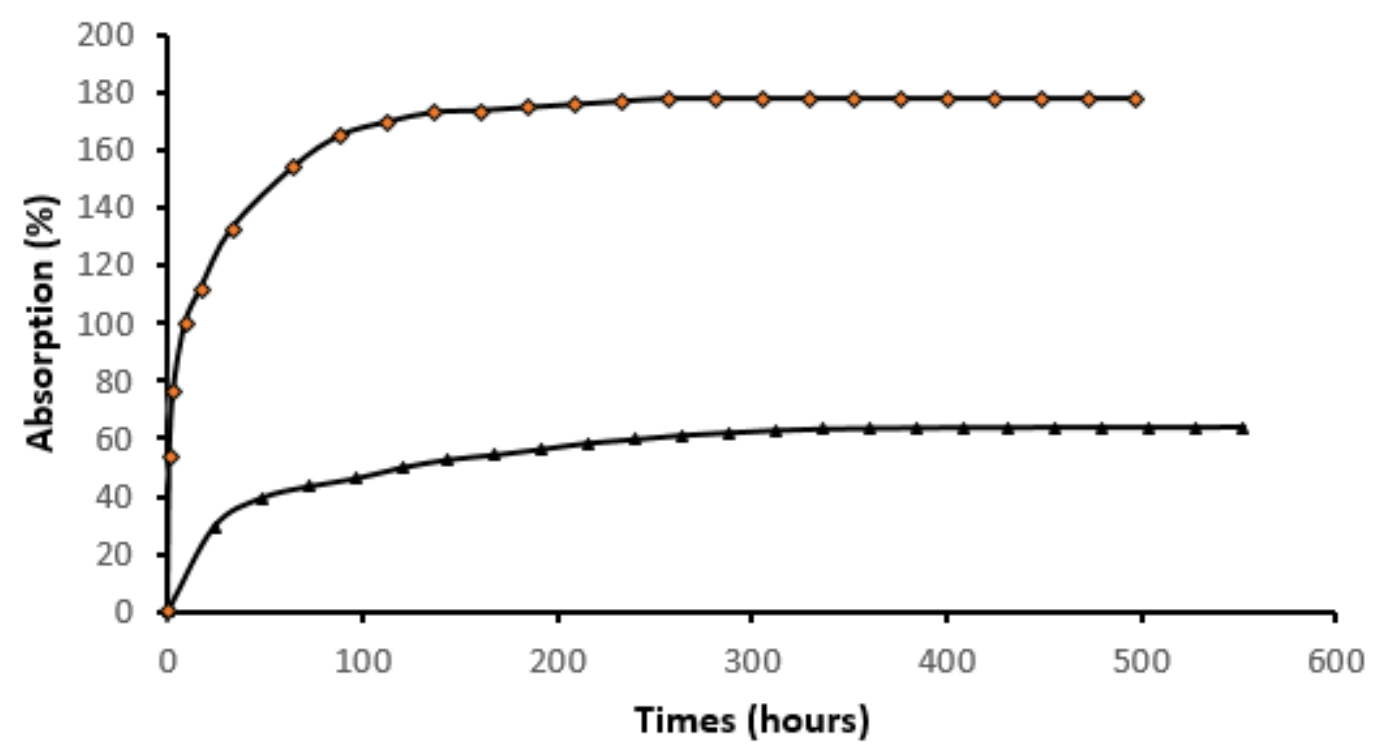

$\longrightarrow$ Palmyra $\rightarrow$ Rattan

Figure 9

Kinematics of absorption of specimens from the palmyra and rattan woods

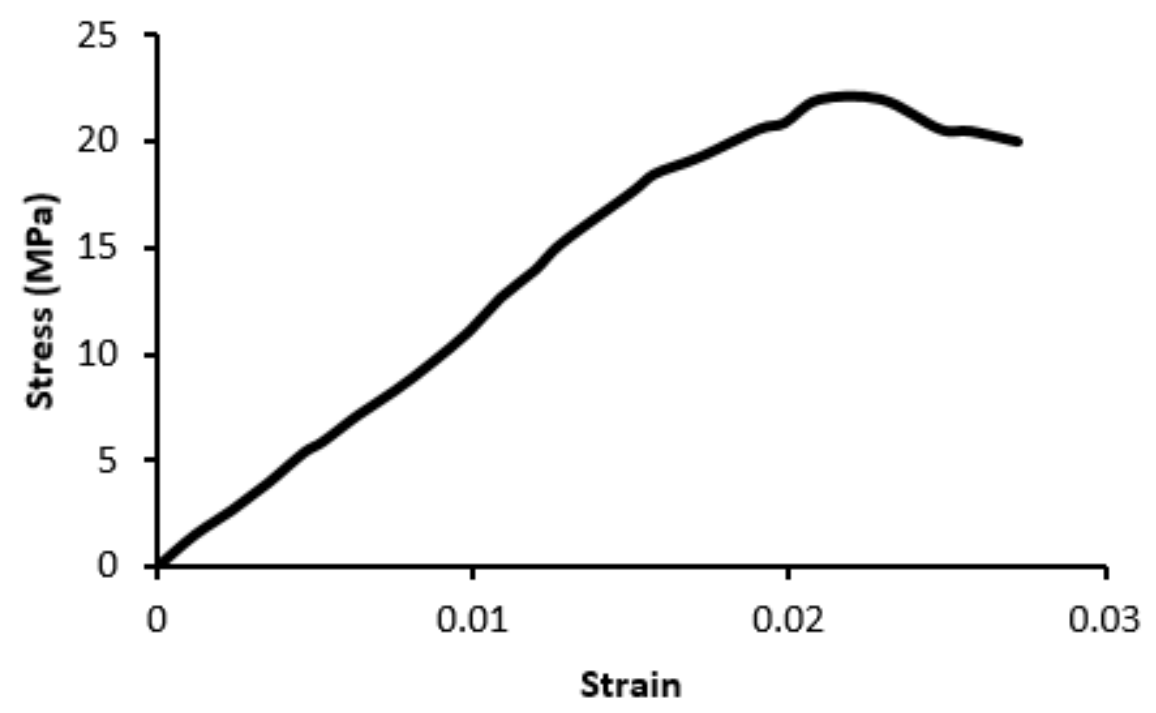

Figure 10

Stress-strain curve of the rattan wood in tension 


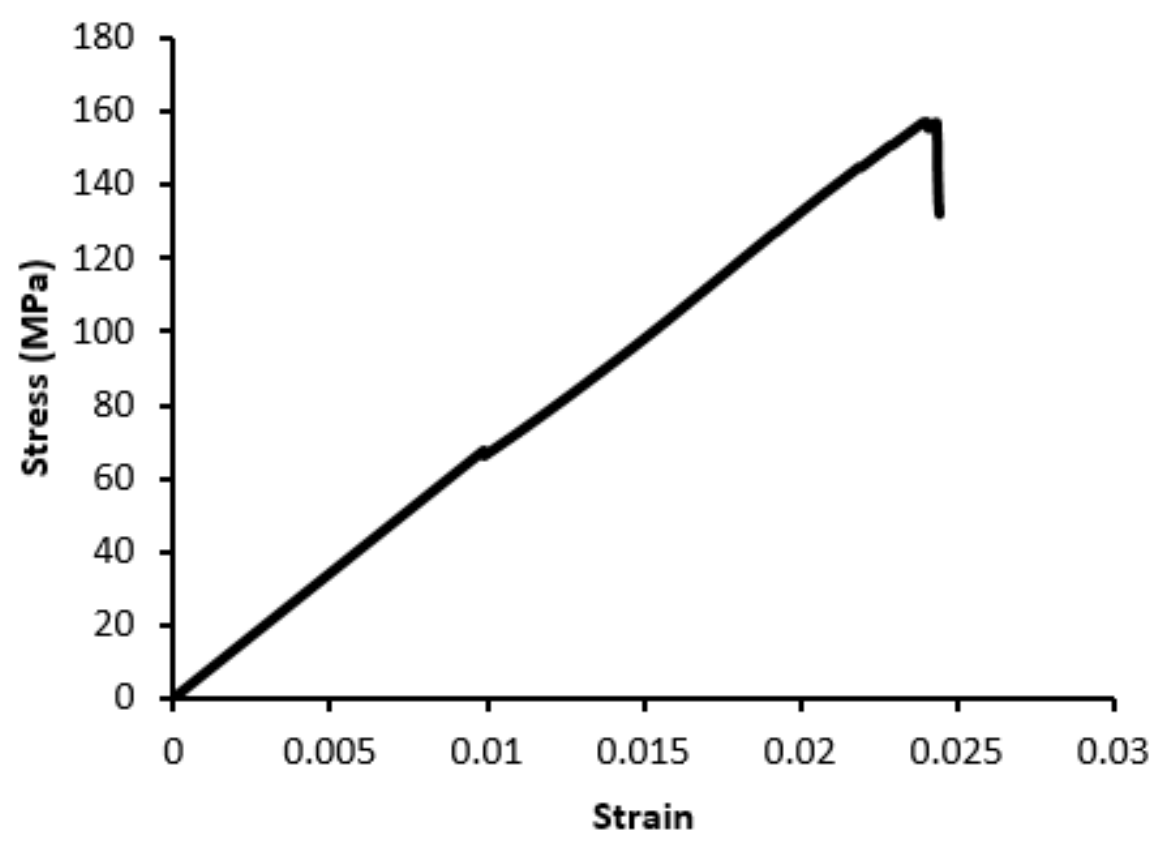

Figure 11

Stress-strain curve of the Palmyra wood in tension

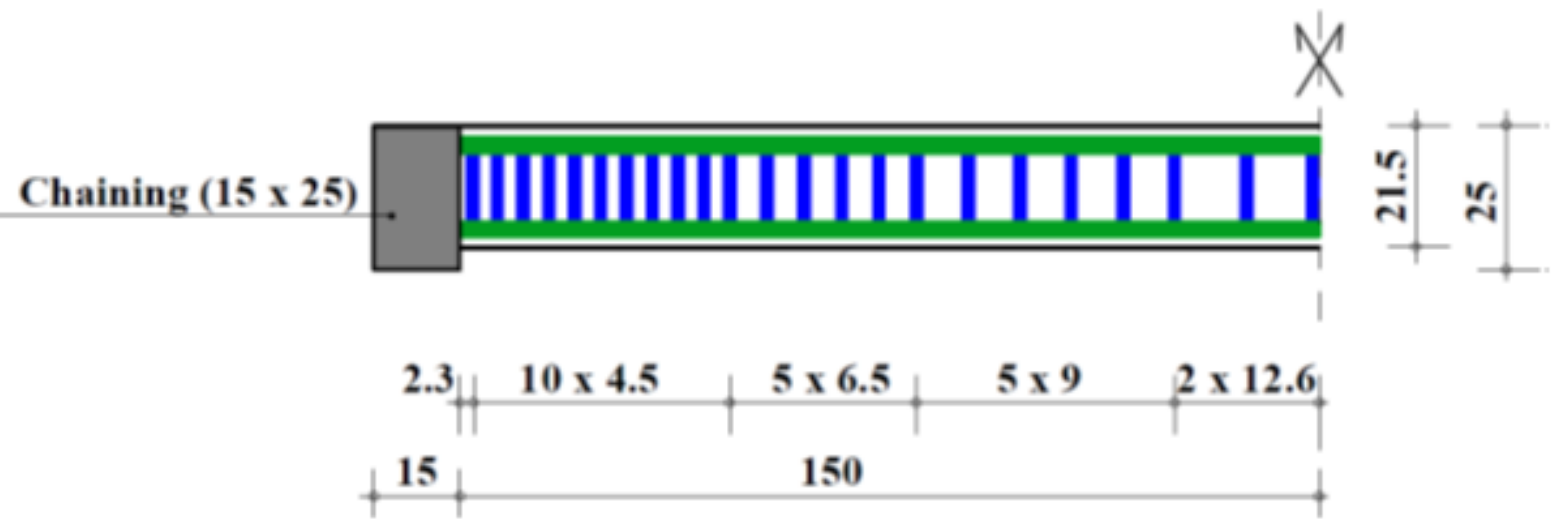

Figure 12

Distribution of transverse reinforcements on half of the rib 

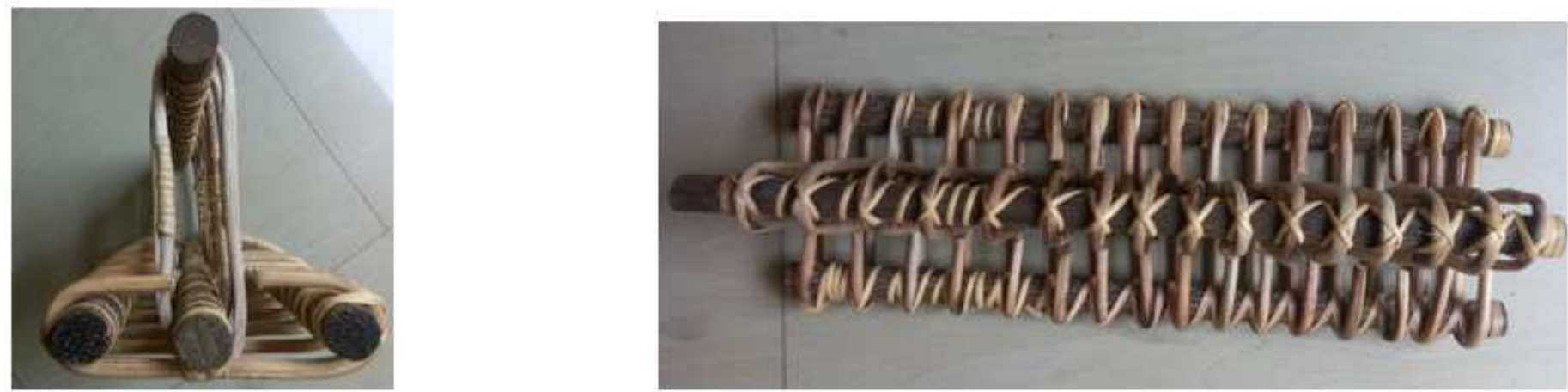

Figure 13

Rib reinforcement prototype

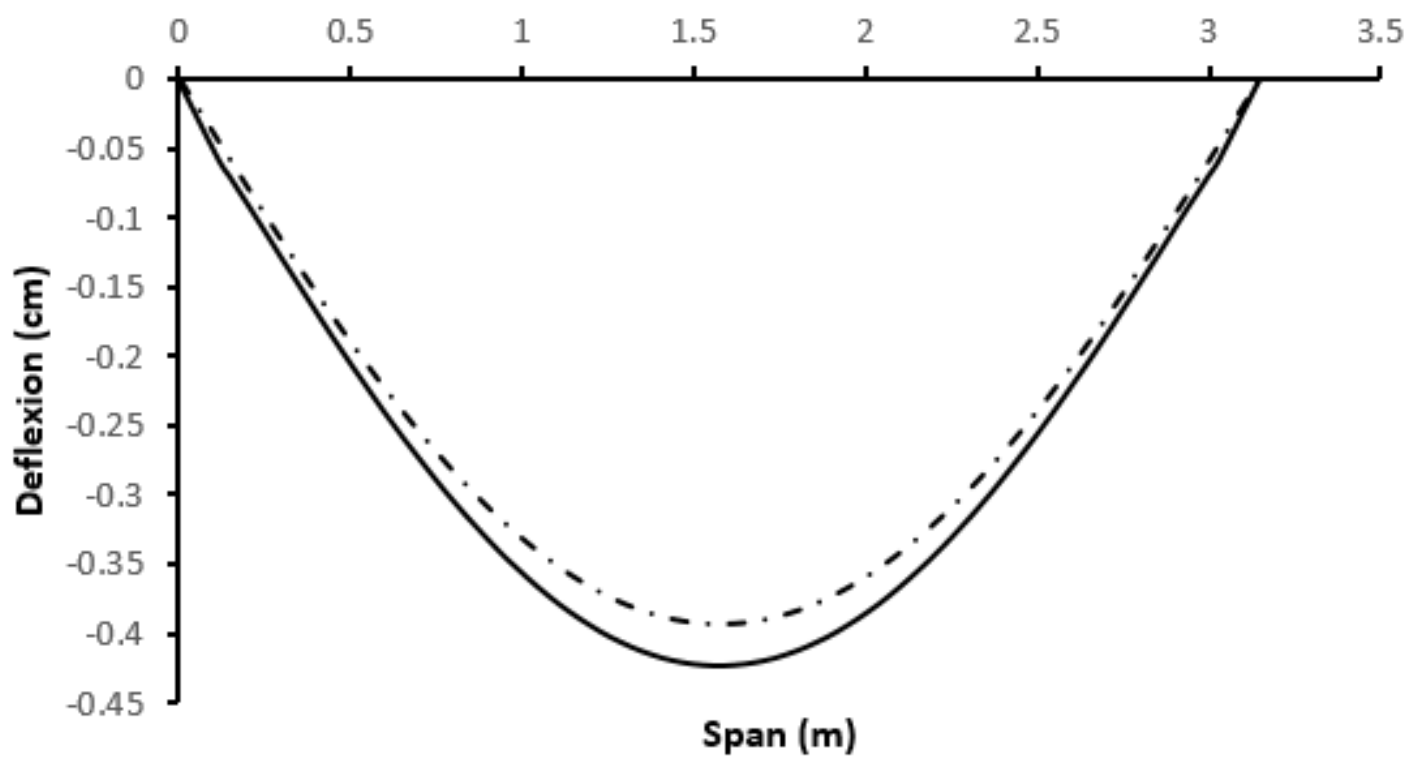

- - - Numerical curve theoretical curve

Figure 14

Comparative deformations of the rib by analytical and numerical calculations 


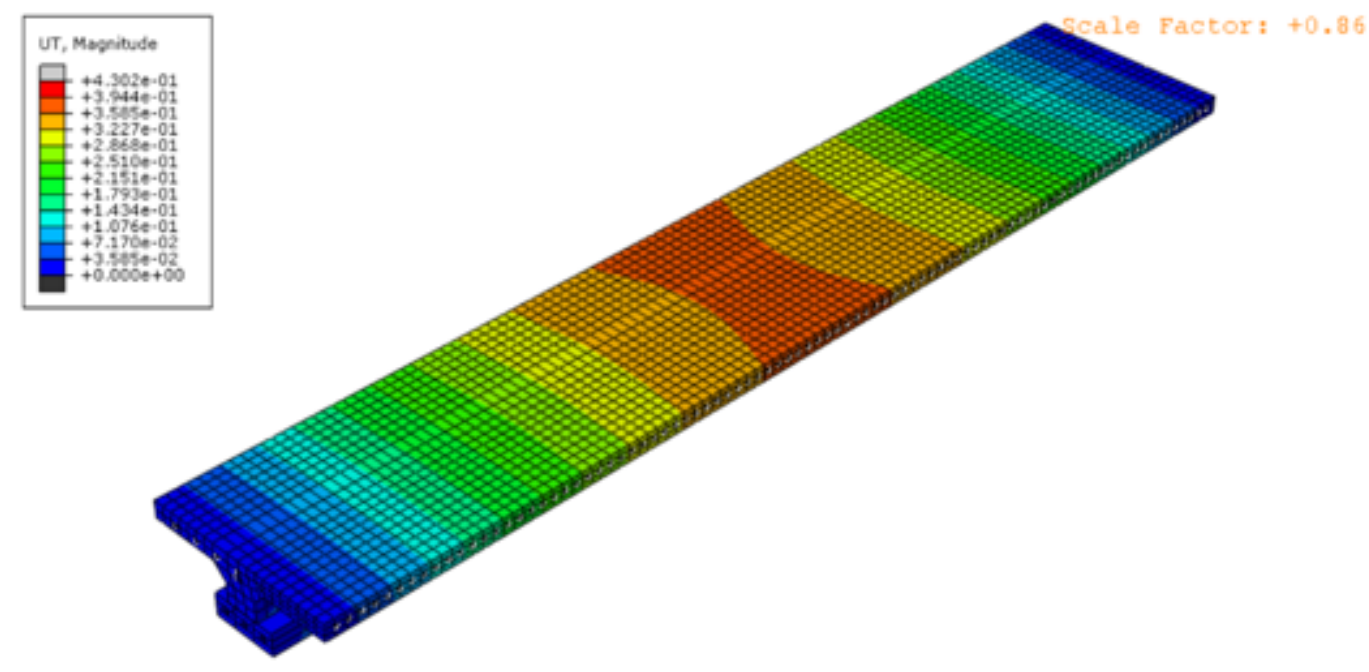

Figure 15

Rib deformation state mapping 